Universidade de São Paulo

Instituto de Biociências

Camila Celestino Hohlenwerger

A estrutura da paisagem e o potencial controle das "cigarrinhas-das-pastagens"

Landscape structure and the potential control of "pasture sharpshooters"

São Paulo

2016 
Camila Celestino Hohlenwerger

\title{
A estrutura da paisagem e o potencial controle das "cigarrinhas-das-pastagens"
}

\section{Landscape structure and the potential control of "pasture sharpshooters"}

\begin{abstract}
Dissertação apresentada ao Instituto de Biociências da Universidade de São Paulo, para a obtenção de Título de Mestre em Ecologia, na Área de Ecologia de ecossistemas terrestres e aquáticos.
\end{abstract}

Orientador(a): Jean Paul Walter Metzger

São Paulo

2016 


\section{Ficha Catalográfica}

Hohlenwerger, Camila Celestino

Efeitos da estrutura da paisagem no processo de predação em áreas de pasto da Mata Atlântica

54 páginas

Dissertação (Mestrado) - Instituto de Biociências da Universidade de São Paulo. Departamento de Ecologia

1. Ecologia de paisagem 2. Serviços ecossistêmicos 3. Controle de pragas 4 .

Procedimentos metodológicos

Universidade de São Paulo. Instituto de Biociências. Departamento de Ecologia.

Comissão Julgadora:

Prof. Dr. Sebastian Meyer

Prof(a). Dr(a). Rozely Ferreira dos Santos

Orientador Dr. Jean Paul Walter Metzger 


\section{Dedicatória}

Dedico essa dissertação aos meus pilares de força: Deus, minha vó Sônia Silva, minha mãe Kátia Quadros, minha família, e meu namorado e companheiro Bruno Travassos. 


\section{Epígrafe}

O amor é uma energia atemporal, que não se limita a tempo ou espaço.

Kátia Quadros 


\section{Agradecimentos}

Mais uma etapa concluída, portanto, me sinto na obrigação de começar os agradecimentos pelas pessoas que me fizeram ser capaz de inicia-la. Agradeço a Deus pela força e amor, a minha mãe Kátia e minha vó Sônia pela dedicação, perseverança e amor que me fazem sentir que sou capaz de ir mais longe, ao meu companheiro e namorado Bruno por todo apoio e amor incondicional e a meus pais do coração Eliana e Liomar que sempre acreditam em mim, e ao meu pai Hermano pelo apoio.

Agradeço em especial ao meu orientador Jean Paul que me deu essa oportunidade e apostou que eu ia ser capaz de desenvolver essa dissertação. Obrigada pelo apoio, Jean. Aos membros do LEPAC que estavam sempre dispostos a me apoiar e ajudar. Agradecimentos especiais a Larissa pela ajuda desde antes da seleção, e depois com todas as dicas maravilhosas sobre o campo. A Natália, Felipe, Adrian, Chico e Leandro pela grande ajuda com as análises estatísticas e espaciais. A Greet e Melina pelo apoio e ajuda nas análises estatísticas. Aos membros do meu comitê de acompanhamento Elizabeth e Cristina por toda ajuda e sugestões. A todos que me ajudaram no campo, Bruno, Jeniffer, Ana, Danilo, Eneias, Leandro, André, Diego, Fernando, Vinicius, Lucas e ao pessoal da casa em Joanópolis. Aos motoristas do IB, Israel, Amaral e Waldir. Ao técnico do Lepac, Welignton por nos socorrer quando as máquinas não querem mais trabalhar pra nós. A Vera por ser mais do que uma profissional competente e nos ajudar com a burocracia e logística com amor e carinho. E aos amigos queridos que graças a Deus são muitos e não vou poder citar um a um, obrigada pelo apoio. Agradeço a FAPESP e a CAPES pelo financiamento. Se tiver uma palavra que define essa dissertação, essa palavra é GRATIDÃO! 


\section{Resumo}

\section{A estrutura da paisagem e o potencial controle das "cigarrinhas-das- pastagens"}

O controle biológico de pragas é um importante serviço ecossistêmico em áreas agrícolas e de pastagem, podendo trazer tanto benefícios econômicos quanto ambientais. Em áreas de pastagens tropicais, as a cigarrinhas-das-pastagens podem trazer prejuízos da ordem de US\$800 milhões por ano, sendo assim uma praga de grande importância. Para entendermos os fatores que potencialmente regulam o controle biológico destas cigarrinhas no nível da paisagem, nós avaliamos, através de experimentos de predação, o efeito da quantidade de cobertura florestal, do tamanho do fragmento e da distância na matriz ao fragmento no processo de predação. Além disso, testamos o efeito de diferentes procedimentos metodológico na detecção de padrões de relação entre o potencial controle de pragas e a estrutura da paisagem. Trabalhamos com nove paisagens inseridas na região de Mata Atlântica, e para cada paisagem utilizamos três transectos de $100 \mathrm{~m}$ de cumprimento para dentro das pastagens, ortogonalmente dispostos a partir de uma borda florestal. A taxa de predação apresentou uma relação positiva com a cobertura florestal no raio de $400 \mathrm{~m}$ e com o tamanho do fragmento, e uma relação negativa com a distância ao fragmento florestal. Os padrões de predação variaram com o tipo de presa utilizado e com o tempo de exposição do experimento. O experimento do tipo sentinel prey (com presas reais que são pragas comuns na região - Deois flavopicta) evidenciou padrões fracos com a cobertura florestal no raio de $3 \mathrm{~km}$, enquanto o experimento com "dummy caterpillars" (com presas artificiais em formato de lagartas) evidenciou padrões mais claros associados, principalmente, com a cobertura florestal no raio de $400 \mathrm{~m}$ e com o tamanho do fragmento. $\mathrm{O}$ efeito negativo da distância ao fragmento florestal só ficou claro com tempos de exposição mais longos (96 horas). O processo de predação na matriz é assim influenciado pela estrutura da paisagem, particularmente em escala mais locais $(400 \mathrm{~m})$, e os diferentes tipos de presas e tempos de exposição de experimentos de predação influenciam nos padrões ecológicos que emergem. Nosso trabalho evidência a importância do manejo da estrutura da paisagem em áreas agrícolas para otimizar o oferecimento do serviço de controle de pragas, bem como a necessidade de se utilizar mais de um tipo de experimento para avaliar o processo de predação. 
Índice

Introdução Geral

Referências

Capítulo único: Título

Introduction

Methods

Results 30

Discussion 34

Final remarks 40

References 41

Supplementary material 48

Conclusão final 


\section{Introdução Geral}

Com a publicação da Avaliação Ecossistêmica do Milênio (2005) foi possível não apenas sintetizar o conhecimento sobre o estado dos ecossistemas globais, mas também reconhecer o valor dos serviços ecossistêmicos para o bem estar humano. Esse estudo é, portanto um marco na literatura internacional, que alavancou os estudos sobre serviços ecossistêmicos (Nilchoson et al. 2009; Balvanera et al. 2012; Costanza and Kubiszewski, 2012). Um dos motivos para o rápido crescimento destes estudos é a necessidade crescente de compreender as relações entre os processos ecossistêmicos e os benefícios que o homem recebe a partir desses processos (MEA, 2005; Balvanera et al. 2012). As intensas modificações dos ambientes naturais (Foley et al. 2005) e o aumento na demanda por benefícios derivados dos ecossistemas (Carpenter et al. 2009) tornam urgente a compreensão das relações entre os processos ecológicos derivados da biodiversidade e os serviços ecossistêmicos resultantes.

Nesse contexto, o serviço de controle natural de pragas se destaca devido ao seu potencial econômico e ambiental (Ostman et al. 2003; Bianchi et al. 2006). Cerca de $10 \%$ da produção agrícola do mundo é perdida devido à ação de pragas (Oerke, 2006). Além disso, cerca de 2,5 milhões de toneladas de pesticidas são aplicados às culturas agrícolas em todo o mundo (van der Werf, 1996), trazendo malefícios tanto ambientais quanto à saúde humana (Pimentel et al. 1992). Apesar dos estímulos econômicos e ambientais, são poucas as informações sobre os benefícios de estratégias alternativas de controle pragas, como o controle natural (Ostman et al. 2003). 
O sucesso do serviço de controle de pragas depende, em grande parte, da biodiversidade que desempenha esse serviço (Bianchi et al. 2006). Em geral, comunidades de inimigos naturais mais diversas são mais eficientes no controle de pragas (Tscharntke et al. 2005). Nesse contexto, a estrutura da paisagem é importante para a manutenção desse serviço, uma vez que ela pode modular a diversidade de espécies em matrizes agrícolas (Bruhl et al. 2003; Jones et al. 2005; Tscharntke et al. 2008). Paisagens agrícolas com estruturas mais adequadas para as espécies nativas, contendo, por exemplo, fragmentos florestais de maior tamanho e cobertura florestal em maior quantidade, possibilitam o aumento da diversidade biológica nas matrizes agrícolas (Tremblay et al. 2001; Bruhl et al. 2003; Bianchi et al. 2006 ; Hendrickx et al. 2007). Esse aumento na diversidade de espécies pode, por exemplo, favorecer o serviço de controle de pragas através do aumento na abundância das espécies mais eficientes no processo de predação, ou então pelo aumento de espécies insetívoras com dietas complementares, permitindo assim a ação num rol mais amplo de presas. Dessa forma, compreender como a estrutura da paisagem, em particular a abundância e arranjo espacial das áreas florestais, influencia o processo ecológico de predação na matriz, pode também possibilitar um melhor entendimento do serviço ecossistêmico de controle de pragas.

A análise das relações entre estrutura da paisagem, processos ecológicos e serviços ecossistêmicos é particularmente relevante na região da Floresta de Mata Atlântica (Joly et al. 2014), que apresenta altas taxas de endemismo e diversidade biológica (Mittermeier et al. 2005), além de ser também um dos biomas mais ameaçados no mundo (Myers et al. 2000). A expansão humana e agropecuária são os principais causadores da intensa fragmentação e perda de habitat nesse bioma (Ribeiro et al. 2012). Atualmente, a Mata Atlântica possui apenas cerca 
de $12 \%$ da sua extensão original, com a maioria dos remanescentes distribuídos em pequenos fragmentos (Ribeiro et al. 2012).

A maior parte dos remanescentes florestais de Mata Atlântica está imersa em matrizes de pastagem (Wassenaar et al. 2007). Em particular, estima-se que só no estado de São Paulo, as áreas de pastagem cheguem a aproximadamente 8 milhões de hectares (Nogueira da Costa, 2011). Dentre as matrizes agropecuárias, a matriz de pastagem é considerada uma das mais inóspitas para biodiversidade florestal (Gascon et al. 1999). A hostilidade da matriz de pastagem é devida principalmente à alta dissimilaridade ao habitat florestal, à simplificação da vegetação (Guevara et al. 1992; De la mora et al. 2013) e ao alto risco de predação que sofrem algumas espécies florestais que transitam por estas matrizes (Zollner e Lima 2005; Roth II et al. 2006). Esta hostilidade pode ser amplificada quando o pasto é dominado por espécies de gramíneas exóticas como, por exemplo, as do gênero Urochloa (sinônimo de Brachiaria), o que parece ser o caso de boa parte das áreas de pastagem da Mata Atlântica (Alvin et al. 2002). A vegetação simples e homogênea (Guevara et al. 1992), associada aos baixos níveis de diversidade biológica (Gasgon et al., 1999), podem tornar as matrizes de pastagens susceptíveis a algumas pragas, como, por exemplo, as cigarrinhas-daspastagens (Homoptera, Cercopidae) (e.g. Deois flavopicta, Deois schach e Zulia entreriana) (Valério et al., 1988, Oliveira, 1997).

Dentre os insetos-praga de importância econômica, as cigarrinhasdas-pastagens são as principais responsáveis por danos econômicos na América Tropical (Valério et al., 2005), causando perdas de 10 a 100\% das pastagens (Oliveira, 1997). Estima-se que os prejuízos econômicos associados às cigarrinhas-das-pastagens são da ordem de US\$ 800 milhões por ano, segundo estimativas da Embrapa Gado de Corte (Informe Itambé, 2013). As cigarrinhas são responsáveis pelo 
amarelecimento das pastagens, pois ao se alimentarem da seiva das folhas e colmos introduzem toxinas que levam ao seu secamento (Pires et al. 2000; Valério et al. 2005), ou à morte do perfilho ou da touceira, tornando o capim impalatável (Gallo et al. 2002). Dado que a maioria da pecuária de corte no Brasil é do tipo extensiva, o extermínio da praga de modo intensivo pela aplicação de inseticidas é inviável (Valério et al. 2005). Apesar do pouco investimento, o controle natural através de agentes biológicos apresenta muito potencial, sendo também uma estratégia economicamente viável (Valério et al. 2005). Nesse contexto, áreas florestais adjacentes a matrizes de pastagem podem atuar como fonte de potenciais predadores de cigarrinhas-das-pastagens, favorecendo o controle biológico natural (Bianchi et al. 2006). Devido a isso, compreender como componentes da estrutura da paisagem associados às áreas florestais influenciam as taxas de predação na matriz pode favorecer o desenvolvimento de estratégias de controle que envolvam, pelo menos parcialmente, o controle biológico de pragas.

Dada a expansão e recente valorização dos estudos de serviços ecossistêmicos e diante da importância do serviço de controle de pragas em pastagens, é necessário o uso de métodos que permitam acessar esse serviço de forma sistemática e rápida. Atualmente, há dois principais métodos de quantificação do processo de predação que podem ser muito utilizados para estudos de controle de praga: sentinel prey e dummy caterpillars (Howe et al., 2009; Rusch et al 2016). Ambos os experimentos envolvem a disponibilização de presas e a contabilização das taxas de predação após um período de exposição das presas (Howe et al. 2009). No experimento do tipo sentinel prey, a presa disponibilizada é um organismo real, podendo estar vivo ou morto (O'neal et al. 2005; Howe et al. 2009; De la Mora et al. 2015). Já no experimento com dummy caterpillars, a presa é artificial, normalmente feita a partir de 
plasticina e de modo que se pareça com uma espécie específica (Howe et al. 2009; Molleman et al. 2015). Ambos os métodos envolvem vantagens e limitações, inerentes ao método utilizado. No experimento com dummy caterpillars, a maleabilidade da plasticina permite identificar o tipo de predador (e.g. artrópodes, mamíferos, aves) através das marcas de predação deixadas no modelo (Molleman et al. 2015). No entanto, esse experimento não apresenta os sinais químicos referentes a uma presa real e que são utilizados pelos predadores (Sam et al. 2015), fazendo com que as taxas de predação possam ser subavaliadas (Vet and Dicke, 1992). No experimento com sentinel prey, apesar de não ser possível identificar o predador através de marcas na presa (pelo fato da presa ser real), esta apresenta os sinais químicos e visuais reais (Howe et al. 2009). Apesar das diferenças específicas de cada um dos dois métodos (Howe et al. 2009) e do extenso uso desses métodos para avaliar o processo de predação (Jordani et al. 2015; Rusch et al. 2016), não se sabe como essas variações metodológicas influenciam as respostas de predação e interferem na análise de padrões ecológicos, como a relação entre predação e estrutura da paisagem (Rusch et al. 2016).

Neste estudo, procuramos compreender: (1) como a estrutura da paisagem, em particular a cobertura florestal, o tamanho e a distância a fragmentos florestais, influenciam o processo de predação em matrizes de pastagem; (2) qual o efeito de diferentes métodos de estimativa de predação sobre a detecção do padrão de relação entre estrutura da paisagem e o processo de predação na matriz. Através de uma abordagem experimental em 9 paisagens fragmentadas de Mata Atlântica, nós observamos que a cobertura florestal em níveis espaciais menores (raio de $400 \mathrm{~m}$ ), o tamanho do fragmento florestal e a distância à borda do fragmento florestal afetam a taxa de predação na matriz de pasto. Além disso, este estudo mostra, pela primeira vez, que diferentes 
métodos de estimativa de predação evidenciam diferentes padrões de relação entre as taxas de predação e a estrutura da paisagem.

\section{Referências}

Alvin, M.J., Brotel., M.A., Xavier, D.F. 2002. As principais pragas do país. Comunicado Técnico, Ministério da Agricultura, Pecuária e Abastecimento.

Balvanera, P., Uriarte, M., Almeida-Lenero, L., Altesor, A., DeClerck, F., Gardner, T., Hall, J., Lara, A., Laterra, P., Pena-Claros, M., Silva Matos, D.M., Vogl, A.D., Romero-Duque, L.P., Arreola, L.F., Caro-Borrero, A.P., Gallego, F., Jain, M., Little, C., Xavier, R.O., Paruelo, J.M., Peinado, J.E., Poorter, L., Ascarrunz , N., Correa, F., Cunha-Santino, M.B., Hernandez-Sanchez, A.B., Vallejos, M. 2012. Ecosystem services research in Latin America: The state of the art. Ecosystem Services 2, 56-70.

Bianchi, F.J.J.A., Booij, C.J.H. e Tscharntke, T., 2006. Sustainable pest regulation in agricultural landscapes: a review on landscape composition, biodiversity and natural pest control. Proceedings of the Royal Society 273, 1715-1727.

Bruhl, C.A., Eltz, T., Linsenmair, K. E.2003. Size does matter - effects of tropical rainforest fragmentation on the leaf litter ant community in Sabah, Malaysia. Biodiversity and Conservation 12, 1371-1389.

Carpenter, S.R., Mooney, H.A., Agard, J., Capistrano, D., DeFries, R.S., Díaz, S., Dietz, T., Duraiappa, A.T. , Oteng-Yeboah, A., Pereira, H.M., Perrings, C., Reid, W.V., Sarukhan, J., Scholes, R.J., Whyte, A. Science for managing ecosystem services: beyond the millennium ecosystem assessment, Proceedings of Natural Academy of Sciences106, 1305-1312.

Costanza, R., Kubiszewski, I. 2012. The authorship structure of "ecosystem services" as a transdisciplinary field of scholarship. Ecosystem Services 1, 16-25.

De la Mora, A.A., Murnen, C.J., Philpott, S.M. 2013. Local and landscape drivers of biodiversity of four groups of ants in coffee landscapes. Biodiversity and Conservation 22, 871-888.

De la Mora, A.A., García-Ballinas, J.A., Philpott, S.M. 2015. Local, landscape, and diversity drivers of predation services provided by ants in a coffee landscape in Chiapas, Mexico. Agriculture, Ecosystems and Environment 201, 83-91.

Foley J.A., DeFries R., Asner G.P., Barford C., Bonan G., Carpenter S.R., Chapin F.S., Coe M.T., Daily G.C., Gibbs H.K., Helkowski 
J.H., Holloway T., Howard E.A., Kucharik C.J., Monfreda C., Patz J.A., Prentice C., Ramankutty N., Snyder P.K., 2005. Global Consequences of Land Use. Science 309, 570-574

Gallo, D., Nakano, O., Silveira Neto, S., Carvalho, R. P. L., Baptista, G. C., Berti Filho, E., Parra, J. R. P., Zucchi, R. A., Alves, S. B., Vendramim, J. D., Marchini, L.C., Lopes, J. R. S., Omoto, C. 2002. Entomologia Agrícola. Piracicaba, FEALQ. 920.

Gascon, C., Lovejoy, T.E., Bierregaard Jr., R.O., Malcolm, J.R., Stouer, P.C., Vasconcelos, H.L., Laurance, W.F., Zimmerman, B., Tocher,M., Borges, S. 1999. Matrix habitat and species richness in tropical forest remnants. Biological Conservation 91, 223-229.

Guevara, S., Meave, J., Moreno-Casasola, P., Laborde, J. 1992. Floristic composition and structure of vegetation under isolated trees in neotropical pastures. Journal of Vegetation Science 3, 655-664.

Hendrickx, F, Maelfait, J., Van Wingerden, W., Schweiger, O., Speelmans, M., Aviron, S., Augentein, S., Billeter, L., Bailey, D., Bukacek, R., Burel, R., Dienkotter, T., Dirksen, J., Herzog, F., Liira, J., Roubalova, M., Vandomme, V., Bugter, R. 2007. How landscape structure, land-use intensity and habitat diversity affect components of total arthropod diversity in agricultural landscapes. Journal of Applied Ecology 44, 340-351.

Howe, A., Lövei, G.L., Nachman, G. 2009. Dummy caterpillars as a simple method to assess predation rates on invertebrates in a tropical agroecosystem. Entomologia Experimentalis et Applicata 131, 325-329.

Informe Itambé. 2013. Cigarrinhas-das-pastagens geram prejuizos em torno de U\$800 milhões por ano no Brasil. Disponível em: http://www.itambe.com.br/download/2828/cadernoAgropecuario.as px.

Joly, C.A., Metzger, J.P., Tabarelli, M. 2014. Experiences from the Brazilian Atlantic Forest: ecological findings and conservation initiatives. New Phytologist 204, 459-473.

Jones, G.A., Sieving, K.E., Jacobson, S. K. 2005. Avian diversity and functional insectivory on north-central Florida farmlands. Conservation Biology 19, 1234-1245.

Millennium Ecosystem Assessment. 2005. Ecosystems and Human Wellbeing: Biodiversity Synthesis (World Resources Institute, 2005).

Mittermeier, R.A., Fonseca, G.A.B., Rylands, A.B., Brandon, K. 2005. A Brief History of Biodiversity Conservation in Brazil. Conservation Biology 19, 601-607.

Myers, N., Mittermeier, R.A., Mittermeier, G.G., Fonseca, G.A.B., Kent, J. 2000. Biodiversity hotspots for conservation priorities. Nature 403, 853-858. 
Molleman, F., Remmel, T., Sam, K. 2015. Phenology of predation on insects in a tropical forest: temporal variation in attack rate on dummy caterpillars. Biotropica, 1-8.

Nicholson, E., Mace, G.M., Armsworth, P.R., Atkinson, G., Buckle, S., Clements, T., Ewers, R.M., Fa, J.E., Gardner, T.A., Gibbons, J., Grenyer, R., Metcalfe, R., Mourato, S., Muuls, M., Osborn, D., Reuman, D.C., Watson, C., Milner-Gulland, E.J. 2009. Priority research areas for ecosystem services in a changing world. Journal of Applied Ecology 46, 1139-1144.

Nogueira da Costa, F. 2011. Crescimento da Fronteira Agrícola no Estado de São Paulo. Disponível em: http://fernandonogueiracosta.wordpress.com/2011/05/05/cresciment o-da-fronteira-agricola-no-estado-de-sao-paulo/.

Oerke, E.C. 2006. Crop losses to pests. Journal of Agricultural Science. 144, 31-43.

Oliveira, M. C. 1997. Pragas das pastagens: uma análise crítica. Disponível em: http://www.forragicultura.com.br/arquivos/Pragas_de_pastagens.PD F.

O'neal, M.E., Zontek, E.L., Landis, D.A., Isaacs, R. 2005. Ground predator abundance affects prey removal in highbush blueberry (Vaccinium corymbosum) fields and can be altered by aisle ground covers. Biological Control 50, 205-222.

Ostman, O., Ekbom, B., Bengtsson, J. 2003 Yield increase attributable to aphid predation by ground-living polyphagous natural enemies in spring barley in Sweden. Ecological Economics 45, 149-158.

Pimentel, D., Acquay, H., Biltonen, M., Rice, P., Silva, M., Nelson, J., Lipner, V., Giordano, S., Horowitz, A., D'Amore, M., 1992. Environmental and human costs of pesticide use. Bioscience 42, 750-760.

Pires, C.S.S, Price, P.W., oliveira, R.C. 2000. Distribution of the Spittlebug Deois flavopicta Stal (Homoptera: Cercopidae) on Wild and Cultivated Host Species. Anais da Sociedade Entomológica do Brasil 29, 401-412.

Ribeiro, D.B., Batista, R., Prado, P.I., Brown Jr, K.S., Freitas, A.V.L. 2012. The importance of small scales to the fruit-feeding butterfly assemblages in a fragmented landscape. Biodiversity Conservation $21,811-827$.

Roth II, T.C., Lima, S.L., Vetter, W.E. 2006. Determinants of predation risk in small wintering birds: the hawk's perspective. Behavioral Ecology and Sociobiology 60, 195-204.

Rusch, A., Chaplin-Kramer, R., Gardiner, M.M., Hawro, V., Holland, J., Landis, D., Thies, C., Tscharntke, T., Weisser, W.W., Winqvist, 
C., Woltz, M., Bommarco, R. 2016. Agricultural landscape simplification reduces natural pest control: A quantitative synthesis. Agriculture, Ecosystems and Environment 221, 198-204.

Sam, K., Remmel, T. and Molleman, F. 2015. Material affects attack rates on dummy caterpillars in tropical forest where arthropod predators dominate: an experiment using clay and dough dummies with green colourants on various plant species. Entomologia Experimentalis et Applicata 157, 317-324.

Tremblay, A., Mineau, P. Stewart, R.K. 2001. Effects of bird predation on some pest insect populations in corn. Agriculture, Ecosystems and Environment 83: 143-152.

Tscharntke, T., Klein, A.M., Kruess, A., Steffan-Dewenter, I., Thies, C. 2005. Landscape perspectives on agricultural intensification and biodiversity - ecosystem service management. Ecology Letters 8, 857-874.

Valério, J.R., Nakano, O. 1988. Danos causados pelo adulto da cigarrinha Zulia entreriana na produção e qualidade de Brachiaria decumbens. Pesquisa Agropecuária Brasileira 23, 447-453.

Valério, J.R., Oliveira, M. C.M. 2005. Parasitismo de ovos de Cigarrinhas-das-Pastagens (Homoptera: Cercopidae) pelo microhimenóptero Anagrus urichi Pickles (Hymenoptera: Mymaridae) na região de Campo Grande, MS. Neotropical Entomology 34,137-138.

Vet, L.E.M and Dicke, M. 1992. Ecology of infochemical use by natural enemies in a tritrophic context. Annual Review of Entomology 37, $141-172$.

H.M.G. 1996. Assessing the impact of pesticides on the environment.

Agriculture, Ecosystems and Environment 60, 81-96.

Wassenaara,T., Gerbera, P., Verburg, P.H., Rosalesa, M., Ibrahimc, M., Steinfelda, H. 2007. Projecting land use changes in the Neotropics: The geography of pasture expansion into forest. Global Environmental Change 17, 86-104.

Zollner, P.A., Lima, S.L. 2005. Behavioral tradesoffs when dispersing across a patchy landscape. Oikos 108, 219-230. 
Capítulo único 


\title{
Landscape structure and the potential control of "pasture
}

\author{
sharpshooters" \\ Camila Celestino Hohlenwerger* and Jean Paul Walter Metzger
}

\begin{abstract}
Biological pest control is an important ecosystem service in agricultural and pastures areas, and can bring both economic and environmental benefits. In areas of tropical pastures, spittlebugs can bring losses of several millions per year, thus being a pest of great importance. To understand the factors that potentially regulate the biological control of these froghoppers, we evaluated through predation experiments the effects of forest cover amount, fragment size and distance in the matrix to fragment on predation process. In addition, we tested the effect of different methodological procedures in the detection of relationships between pest control and landscape structure. We worked with nine landscapes inserted in the Atlantic Forest region, and for each landscape used three transects of $100 \mathrm{~m}$ length inside pastures, orthogonally arranged from the forest edge. Predation rate showed a positive relationship with forest cover within $400 \mathrm{~m}$ and with fragment size, and a negative relationship with distance from forest fragment. Predation patterns varied with the type of prey used and the exposure time of the experiment. The sentinel prey's experiment (with real preys that are common pests in the region - Deois flavopicta) showed weak patterns with forest cover in $3 \mathrm{~km}$, while the dummy caterpillars experiment (with artificial prey on caterpillars' shape) showed clearer patterns mainly associated with forest cover within $400 \mathrm{~m}$, and with fragment size. The negative effect of distance from the forest fragment became clear only with longer exposure times (96 hours). The predation process in the matrix is thus influenced by the landscape structure, particularly in more local scale $(400 \mathrm{~m})$, and different types of prey and exposures times of predation experiments influence the ecological patterns that emerge. Our work highlights the importance of landscape management structure in agricultural areas to optimize the offering of pest control service, as well as the need to use more than one type of experiment to access predation process.
\end{abstract}

Keywords: Landscape ecology, landscape structure, pest control, predation experiments, pasture matrix

Departamento de Ecologia, Universidade de São Paulo, Rua do Matão 314, Travessa 14, 05508-900, São Paulo, SP, Brasil.*E-mail: cch.camila@gmail.com 


\section{Introduction}

In recent decades, much effort has been invested to understand the relationships between changes in landscape composition and configuration, caused in particular by agricultural expansion (Foley et al., 2005), and the effects of those changes on ecological processes (Aertis and Honnay, 2011; Meyer et al, 2015), and ecosystem services.

Ecosystem services are "the benefits that man derives directly or indirectly from ecosystems" (Costanza et al., 1997, 2008; Millennium Ecosystem Assessment 2005; Cardinale et al., 2012). Natural pest control, which is related to ecological predation processes, is one of these services (Wilby and Thomas, 2002). The reduction of pests through natural control brings both economic and environmental benefits as it reduces the loss in production without the negative environmental effects of the use of chemical defenders (Ostman et al., 2003). Natural control can potentially be an important alternative to regulate one of the main pests of pastures in Brazil, locally known as "pasture froghooters". This pest includes several spittlebug species of the suborder Homoptera (Cercopidae). Deois flavopicta is the one of the most important of those species (Valério et al., 2005). By feeding on the sap of the leaf, those species introduces toxins that make the grass unpalatable, reducing the food resources available to cattle. Thus, this pest causes economic losses to livestock producers in the range of US\$ 800 million a year (Informe Itambé).

Agricultural intensification reduces, replaces and simplifies local biodiversity (Tilman et al., 2002; Foley et al., 2005; Tscharntke et al., 2005; Sodhi et al., 2009), subsequently causing changes in the diversity of potential natural enemies that act in pests control through predation process (Andersen and Eltun, 2000). Particularly, the decrease in species 
diversity in a community due to agricultural expansion may result in a decrease in the abundance in the most effective predators or in the diversity of preys that can be controlled, leading to a decrease in pest control (Perfecto et al, 2004; Hooper et al. 2005; Isaacs et al, 2009; Puckett et al, 2009). In this context, forest areas play an important role in maintaining biological diversity in agricultural matrices (Holland and Fahrig, 2000; Tremblay et al, 2001; Benton et al 2002), and thus in being the source of insect pest predators that act in these matrices (Bianchi et al., 2006).

The amount of forest habitats is one of the main parameters of the landscape structure related to the diversity of species in agricultural areas (Jones et al, 2005; Hendrickx et al., 2007, Tscharntke et al., 2008; Jackson and Fahrig, 2015). Because the spatial distribution of forest can be irregular, the amount of forest habitat available for species with different dispersal abilities may varies (Jackson and Fahrig, 2015), making necessary the analysis of habitat at different scales. Also, habitat patch size can regulate population processes by controlling the availability of resources (Connor, et al., 2000; Jordani et al., 2015). Larger patches can have more resource availability, as well as greater diversity and abundance of predators (With et al., 2002; Bruhl et al., 2003; Langellotto and Denno, 2004). Therefore, it is expected that the amount of forest cover at different scales and patch size are related to the diversity of predator species that act in agricultural matrices, potentially assisting in the provision of ecosystem service of pest control.

Furthermore, the increase in species diversity, combined with the increase in the overlapping and complementary functions of the biological community (Hooper et al., 2005), can also increase the number of species with different degrees of tolerance to human 
disturbances (Storch et al., 2005), potentially enhancing the functional spillover of those species in agricultural environments.

Cross-habitat functional spillover is defined as the movement of organisms from one habitat to the other that results in an ecological function to be performed in a place other than the place of living of the organism (Blitzer et al., 2012). This spillover of forest species is one of the processes by which may occur the provision of ecosystem services, such as pest control (Landis et al., 2000; Rusch et al., 2010; Blitzer et al, 2012). As organisms move in the matrix, they may possibly forage in this environment, since it provides alternative food sources (Blitzer et al., 2012). The low tolerance of most forest species to anthropogenic matrices (Koller, 1988; Storch et al., 2005; Hendrickx et al, 2007), associated with the low hospitability of some of these matrices, as pastures (Gascon et al., 1999; Laurence et al. 2011), can make pest control more intense next to forest edges (Tremblay et al., 2001; Hendrickx et al., 2007).

Despite of being an important ecosystem service, the relationships between landscape structure, predation process, and pest control are still poorly studied (Rsuch et al., 2016). The lack of more extensive data on the influence of landscape structure on predation process and pest control service can be related with the difficulty of obtaining field data. Direct assess of predation process in the field is difficult since it depends on the predator activity and those predation events often happens fast (Crawley, 1992; Howe et al., 2009). Because of this, indirect predation assessments are widely used (e.g. Loiselle et al., 2002; Richard and Coley, 2007; Howe et al, 2009; Molleman et al, 2015). Among the indirect ways of assessing the intensity of predation, methods that involve providing and monitoring real or artificial preys are considered the most simple and easy way to obtain quantitative data of predation (Howe et al., 2009). 
Therefore, these methods are being increasingly used (Meyer et al, 2015; Sam et al, 2015). However, the influence of methodological procedures on the detection of predation responses is still poorly known (Howe et al, 2009). Particularly, the effects of the type of prey (Howe et al, 2009; Molleman et al, 2015) and the time of exposure of preys (e.g. Loiselle et al., 2002; Molleman et al, 2015; Sam et al, 2015) should be better explored. Providing different preys and using different exposure times to predation can impede the comparison of results, which may cause confusion in detecting general ecological patterns of predation and pest control.

In this context, the aims of this study are to: (1) test the influence of the amount of forest cover in two different spatial scales in the predation process on pasture matrices; (2) test the influence of forest fragment size in the predation process on pasture matrices; (3) access whether the distance to forest fragments affects predation process; and (4) determine the effects of different methods to access predation process (type of preys and exposure times) on the evaluation of the relationships between landscape structure and predation process.

\section{Methods}

\section{Study region and landscape selection}

This study was conducted in nine fragmented landscapes in CantareiraMantiqueira region of the Atlantic Plateau of São Paulo, Brazil $\left(-22.81^{\circ}-22.81^{\circ},-46.56^{\circ}-45.98^{\circ}\right)\left(\sim 3000 \mathrm{~km}^{2}\right)$. This region is located within the Brazilian Atlantic Forest biome, one of the biomes with the greatest diversity of tropical biota and with highest rates of endemism (Mittermeier et al., 2005). Due to the intense process of fragmentation and habitat loss, this biome is considered one of the most endangered in 
the world and one of the five global biodiversity hotspots (Myers et al., 2000). The Cantareira-Mantiqueira region is recognized by its biodiversity conservation value (MMA, 2007) and corridor function (Rodrigues and Bononi, 2008), and at the same time is considered a crucial area for urban water supply, accounting for about 50\% of the water supply of the city of São Paulo (Whatley and Cunha, 2007).

The region is characterized by convex and steep hills (elevation 800 and $1200 \mathrm{~m}$ ), where most of the remaining forest is reduced to fragments with different successional stages (Arzolla et al., 2011; Romitelli et al., 2015). These landscapes are composed of heterogeneous mosaic of forest fragments, often quite disturbed, and pasture for livestock. The annual rainfall in the study area varies between 1350 and $2000 \mathrm{~mm}$, the average annual temperature ranges between $15^{\circ}-22^{\circ} \mathrm{C}$ (www.cpa.unicamp.br), and the climate is subtropical of altitude(Ventura, 1964).

The study landscapes were selected in order to estimate the effects of forest cover. We adopted the method described in Pascher et al. (2013) to avoid abrupt changes in forest cover at different spatial scales, allowing thus to analyze patterns and processes at various scales (landscapes with 1,2 and $3 \mathrm{~km}$-radius). The selected landscapes presented similar abiotic conditions, as described above. The characteristics of the matrix, particularly the amount of eucalyptus (maximum of $10 \%$ cover), were controlled to guarantee the predominance of pastures in the matrix.

The analysis of the landscape structure was done at two scales. At a larger scale, we selected circular landscapes with a $3 \mathrm{~km}$ radius $(2,830$ ha) in order to represent the scale of effect of birds (Smith et al., 2011), potential invertebrates predators in agricultural matrices (Jones et al., 2005) (Figure 1). Thereafter, we analyze the landscape at the local level 
with radius of $400 \mathrm{~m}$ around each sampling point (centered $50 \mathrm{~m}$ in the matrix from the forest edge). This scale was selected in order to represent the scale of effect of predatory arthropods (De la Mora et al., 2013).

A)

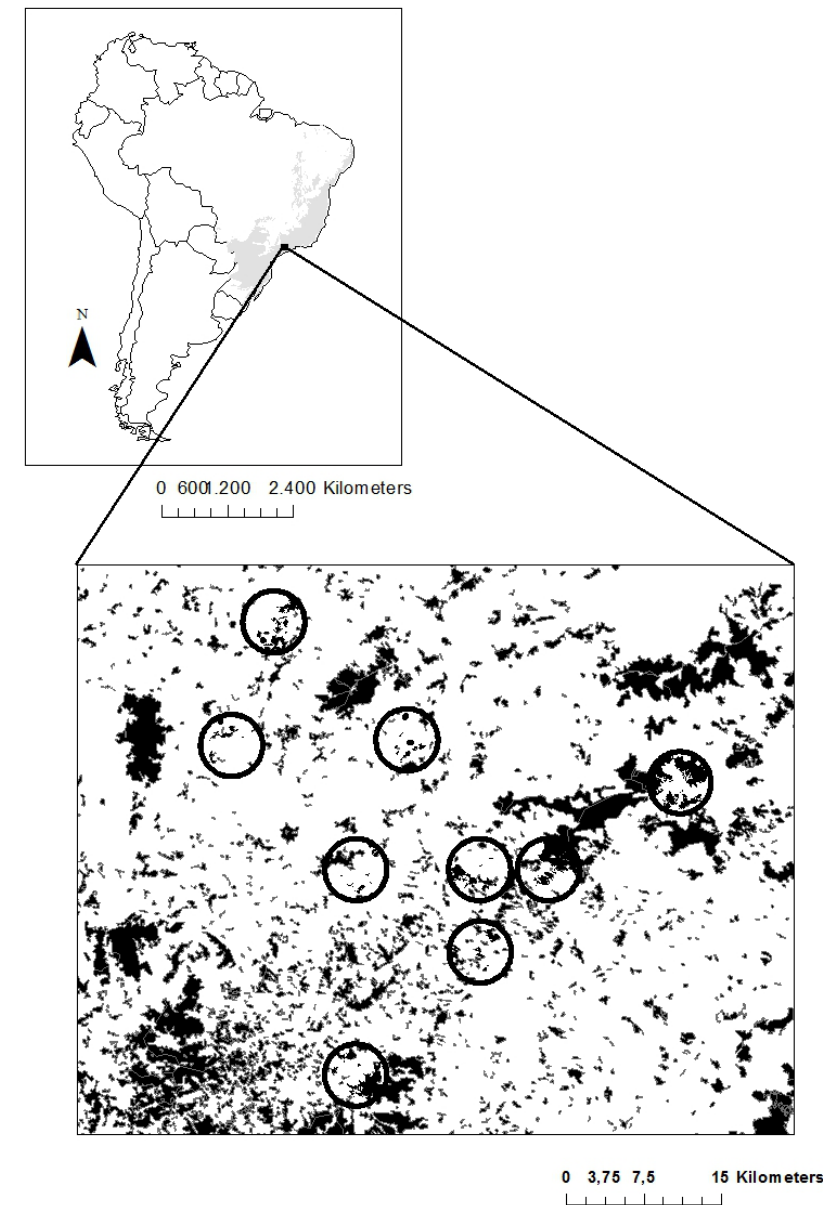

B)

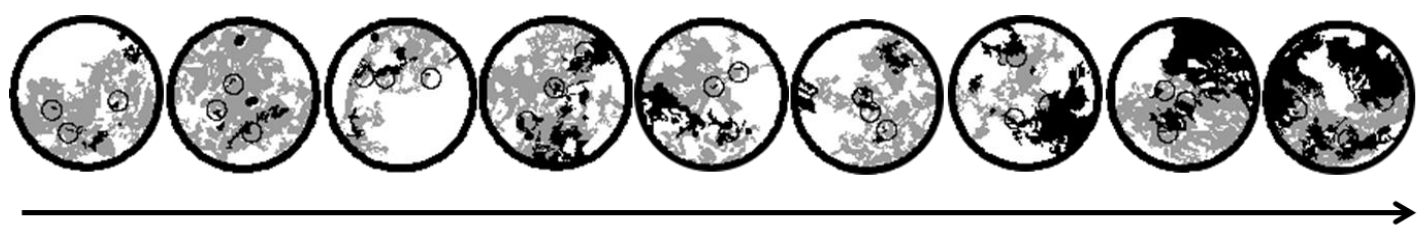

Figure 1: A) Spatial location of the nine experimental landscapes, with $3 \mathrm{~km}$ radius, along the Atlantic Forest region in Brazil (grey area; remnants in black in the bottom panel). B) Amount and spatial distribution of forests (black) and pasture matrix (grey) areas for nine studied landscapes. Local landscapes (with $400 \mathrm{~m}$ radius) are indicated. 


\section{Selection of sampling transects}

Within each landscape three sampling transects were selected using the Sampling Design tool in ArcGIS 10.1. Given the importance of fragment size on ecological processes and considering the risk of the largest fragment of the landscape not being sampled in a completely random selection (given the large number of small fragments), one of the three sampling transects was allocated within the larger landscape fragment. The other two transects were randomly allocated between the remaining fragments greater than 1.5 ha, following a minimum distance of 300 meters between the sampling transects and a maximum distance of 400 meters to a road in order to facilitate access. All sampling transects were allocated at the interface between forest fragments and areas of livestock grazing active or inactive for at most two years. Pastures were composed mostly of grasses of the genus Urochloa (previously known as Brachiaria).

\section{Landscape metrics}

Four landscape metrics were considered: forest cover at landscape $(3 \mathrm{~km}$ radius) and local (400 m radius) levels; fragment size; and distance from forest. There was a low correlation between the amount of forest cover at local and landscape levels $(\mathrm{R}=0.58)$. Forest fragment size was the area of the nearest native vegetation fragment adjacent to the field experiments. Distance from forest (isolation) was measured as the distance of the sampling unit in the transect (see below) to the closest forest edge. The landscape metrics were calculated in ArcGIS 10.1 and Fragstat. 


\section{Field experiments}

The study was conducted for four months starting in January and ending in April 2015. In each of the three sampling transects, a transect of 100 meters length was established in the pasture matrix, perpendicular to the edge of the selected forest fragment. Starting from point zero (at the edge of the forest) six sampling units were placed along the transect spaced 20 meters from each other. In each of these units two types of experiments were placed: sentinel prey (e.g. Prasifka et al., 2004) and dummy caterpillars (e.g. Howe et al., 2009) (Figure 2).

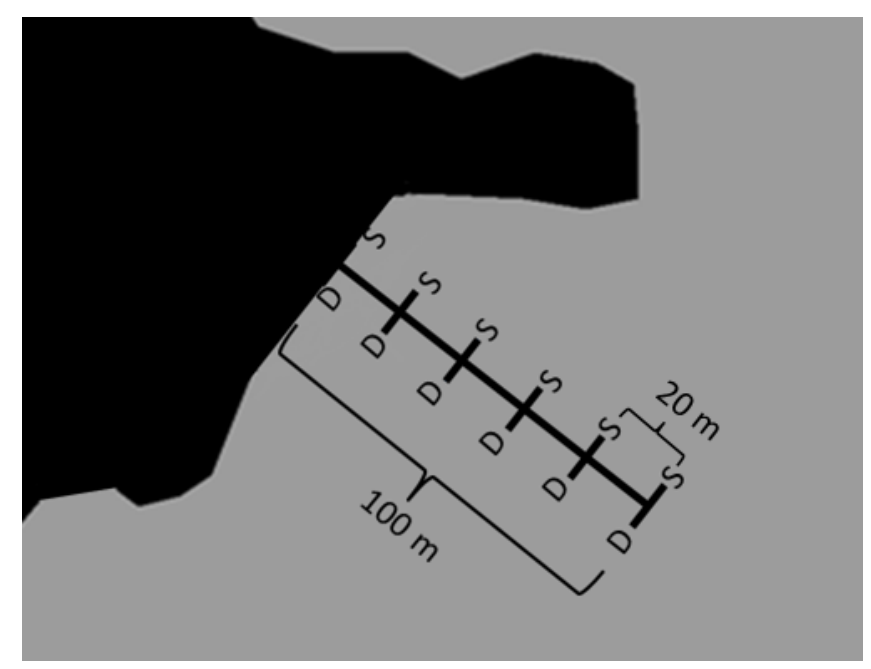

Figure 2: Scheme of sampling transect with the two experiments ( $\mathrm{S}$ - sentinel prey; $\mathrm{D}$ - dummy caterpillars) distant $100 \mathrm{~m}$ from forest edge (black) in the pasture matrix (grey). In each of the six distances from forest edge individuals/models were placed to be exposed.

The sentinel prey experiment type is widely used in predation experiments (Rusch et al., 2016) and consists of providing dead individuals of a species. In this study we used a natural pasture pest Deois flavopicta (homoptera: Cercopidae), which is the most important spittlebug in the study region. Adult feed on the sap of the grass and introduce toxins that can lead to death of the plant. Nymphs stay near to the base of grass and although they do not introduce toxins to the plant while feeding, they unbalance water and nutritional resources of the 
plant. 20 adult individuals were spaced one meter from each other and fixed on top of the grass leaves using superglue. The 20 individuals were exposed for 48 hours. After that period, the numbers of individuals preyed and not-preyed were recorded. We considered preyed individuals those who lost parts of the body (Figure S7).

The dummy caterpillars' experiments are also widely used in predation experiments and allow the identification of the predator through their marks of predation (Howe et al., 2009; Jordani et al., 2015). These experiments consisted of providing 20 identical models simulating real caterpillars, spaced one meter from each other. Models were made of green clay with $40 \mathrm{~mm}$ long and $4 \mathrm{~mm}$ of diameter. As in the sentinel prey experiment, subjects were fixed at the top of the grass leaves using super glue, and had a close plastic tape marking for easy viewing at the time of inspection. The 20 models were exposed to be preyed initially for 48 hours. After this period, there was a check for the presence or absence of predation marks. If there was predation marks, the model was removed (without replacement), and the remaining models were exposed for another 48 hours, totaling 96 hours of exposure. At the end of the 96 hours of the experiment, all models were taken and checked for the presence of predation marks. All models with predation marks had their marks identified at a broad taxonomic level (arthropods, birds or small mammals - Figure S6).

\section{Statistical analysis}

The relationships of landscape metrics (forest cover at the two studied levels, distance to forest fragment and fragment size) with predation rate were evaluated by generalized linear mixed models with binomial distribution (GLMMs; Zuur 2009). To assess the importance of the predation method (type of prey offered and sampling time), the predation 
rate was evaluated considering four different methodological procedures: sentinel prey (48 hours of exposure); dummy caterpillars in the first 48 hours of exposure; dummy caterpillars in all 96 hours of exposure; dummy caterpillars in the second set of 48 hours of exposure. The predation rate was calculated as the proportion of individuals or models preyed, divided by the number of individuals or models initially provided (20 individuals or models) minus individuals or models which were not found on the checking time. Since we do not know if every individual or model lost was preyed, include such data as preyed may overestimate the proportion of predation. Thus, individuals or models that were not found at checking time were removed from the calculation of the proportion of predation (see supplementary material for proportion of individuals or models lost in figure S1). In the second set of 48 hours of dummy caterpillars' experiment, the proportion of predation was calculated as the amount of attacked models divided by the number of models that has not been attacked upon the first 48 hours minus the models which were not found at this checking time.

To consider the fact that there were three sampling transects within each landscape, the transect unit within the landscape was included in the analysis as random effects (Zuur, 2009). As two distances of the same transect are more similar to each other than with the distances of other transects, the transect unit was also included in the analysis as random effects. All four landscape metrics were included in the models as fixed effects. The model selection approach was used to select which of the models better explains the predation rate in the sentinel prey and dummy caterpillars' experiments. The Akaike Information Criterion corrected for small sample sizes (AIC) was used to select the best models for each of the dependent variables (predation rate obtained by different methodological procedures). All analyzes were 
performed using the R package 'Ime4' (R Development Core Team 2014). There was no collinearity and over-dispersion (overdispersion) between the variables used.

\section{Results}

Field experiments were conducted in fragments with 1.7 to 603 ha, with a surrounding forest cover of 10 to $49 \%$ at the landscape level, and $6 \%$ to $63 \%$ at the local level.

The predation rate of sentinel prey's experiment (mean $=56.4 \%$, $\mathrm{sd}=0.22)$ was on average 2.2 times higher than the dummy caterpillars' experiment (mean $=25 \%, \mathrm{sd}=0.14$ ) at the same exposure time (48 hours - Figure 3A) and 1.2 higher when compared with longer (96 hours) caterpillars experiment $($ mean $=47 \%, \mathrm{SD}=0.15$ ) (Figure 3B). The predation rate of dummy caterpillars' experiment within 48 hours of exposure was on average 1.8 times less than within 96 hours (Figure 3C), but the predation was similar in the two sets of 48 hours (Figure 3D). In dummy caterpillars' experiment, most documented predators were arthropods, with $94 \%$ of predation rate at the first 48 hours and $96 \%$ at 96 hours. Birds and mammals had a minor contribution to predations rates, with $4 \%$ at the first 48 hours and $2 \%$ at 96 hours for birds, and with $2 \%$ for mammals at both periods. 

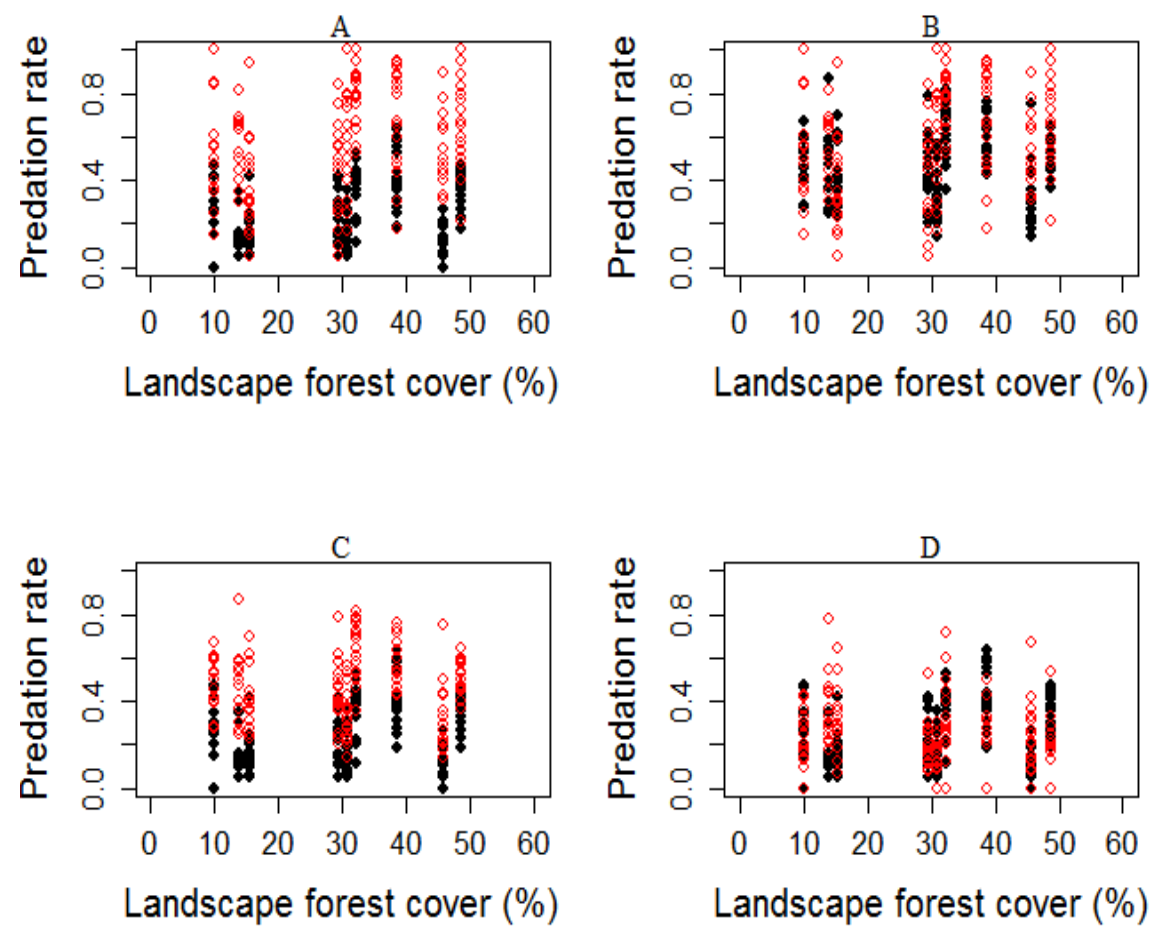

Figure 3: Predation rate compared between methodological procedures: A. Dummy caterpillars first set of 48 hours in black and Sentinel prey in red; B. Dummy caterpillars 96 hours in black and Sentinel prey in red; C. Dummy caterpilars first set of 48 hours in black and 96 hour in red; D. Dummy caterpillars first 48 hours in black and second set of 48 hours in red.

The observed relationship between predation rate and landscape metrics varied according to the methodological procedure used to detect predation (Table 1, Figure 4). For the sentinel prey experiment, no clear pattern was observed, once the null model was among the best models (Table 1), however the landscape forest cover seems to have a positive influence in the predation rate (Figure S2).

In the dummy caterpillars experiment within the first 48 hours of exposure, the size of the fragments appears to be the best predictor. Predation rate is positively associated with the size of the forest fragment, and secondarily with the combination (additive effect) of fragments size with local forest cover (Figure S3). 
In the whole 96 hours of dummy caterpillars' exposure, although the positive effect of the size of the fragment remains, the negative effect of distance from forest and the positive effect of local forest cover begin to better explain the variation in the predation rate (Figure S5).

When evaluating only the second set of 48 hours of dummy caterpillars experiment, we found that the negative effect of distance from forest is accentuated (Table 1 - Figure S4). Given that in the first set of 48 hours of this experiment the effect of distance from forest was not very clear, it can be concluded that the importance of isolation in 96 hours is strongly influenced by the second set of 48 hours of dummy caterpillars exposure.

These results indicate clearly that the type of predation experiment (sentinel prey or dummy caterpillars) and the exposure times influenced the observed relationships, not only highlighting different predictor variables, but also showing different trends (positive or negative) with the same predictor (for example, positive effect of landscape forest cover on predation with sentinel prey and negative effect with dummy caterpillars in the second set of 48 hours; Figure 4).

Table 1: Main parameters of the models relating predation rates with landscape metrics considering four different methodological procedures to evaluate predation (sentinel pray and dummy caterpillars' experiments).

\begin{tabular}{|c|c|c|c|}
\hline a) Sentinel prey models & AICc & $\triangle \mathrm{AICc}$ & weight \\
\hline $\begin{array}{l}\text { Landscape forest cover }+ \\
\text { Local forest cover }\end{array}$ & 935.5 & 0 & 0.149 \\
\hline Landscape forest cover* & & & \\
\hline Distance from forest & 936.3 & 0.77 & 0.101 \\
\hline Landscape forest cover & 936.4 & 0.85 & 0.097 \\
\hline Null model & 936.9 & 1.38 & 0.074 \\
\hline $\begin{array}{l}\text { Landscape forest cover }+ \\
\text { Local forest cover }+ \text { Fragment size }\end{array}$ & 937.0 & 1.48 & 0.071 \\
\hline Local forest cover $*$ Fragment size & 937.1 & 1.52 & 0.069 \\
\hline $\begin{array}{l}\text { b) Dummy caterpillars first } \\
\text { set of } 48 \text { hours models }\end{array}$ & AICc & $\triangle \mathbf{A I C c}$ & weight \\
\hline Fragment size & 644.1 & 0 & 0.245 \\
\hline
\end{tabular}




\begin{tabular}{|c|c|c|c|}
\hline $\begin{array}{l}\text { Fragment size }+ \\
\text { Local forest cover }\end{array}$ & 645.6 & 1.42 & 0.120 \\
\hline $\begin{array}{l}\text { Fragment size }+ \\
\text { Distance from forest }\end{array}$ & 645.8 & 1.64 & 0.108 \\
\hline $\begin{array}{l}\text { Fragment size }+ \\
\text { Landscape forest cover }\end{array}$ & 645.9 & 1.80 & 0.100 \\
\hline $\begin{array}{l}\text { c) Dummy caterpillars } 96 \\
\text { hours models }\end{array}$ & AICc & $\triangle \mathrm{AICc}$ & weight \\
\hline $\begin{array}{l}\text { Distance from forest }+ \\
\text { Local forest cover }\end{array}$ & 656.7 & 0 & 0.416 \\
\hline $\begin{array}{l}\text { Distance from forest } * \\
\text { Local forest cover }\end{array}$ & 658.7 & 1.95 & 0.157 \\
\hline $\begin{array}{l}\text { Distance from forest }+ \\
\text { Local forest cover }+ \text { Fragment size }\end{array}$ & 658.7 & 1.95 & 0.157 \\
\hline $\begin{array}{l}\text { d) Dummy caterpillars second } \\
\text { set of } 48 \text { hours models }\end{array}$ & AICc & $\Delta \mathrm{AICc}$ & weight \\
\hline Distance from forest & 521.4 & 0 & 0.228 \\
\hline $\begin{array}{l}\text { Distance from forest }+ \\
\text { Landscape forest cover }\end{array}$ & 521.9 & 0.50 & 0.177 \\
\hline $\begin{array}{l}\text { Distance from forest }+ \\
\text { Landscape forest cover }+ \text { Local } \\
\text { forest cover }+ \text { Fragment size }\end{array}$ & 522.6 & 1.20 & 0.125 \\
\hline $\begin{array}{l}\text { Distance from forest }+ \\
\text { Local forest cover }\end{array}$ & 522.7 & 1.35 & 0.116 \\
\hline
\end{tabular}

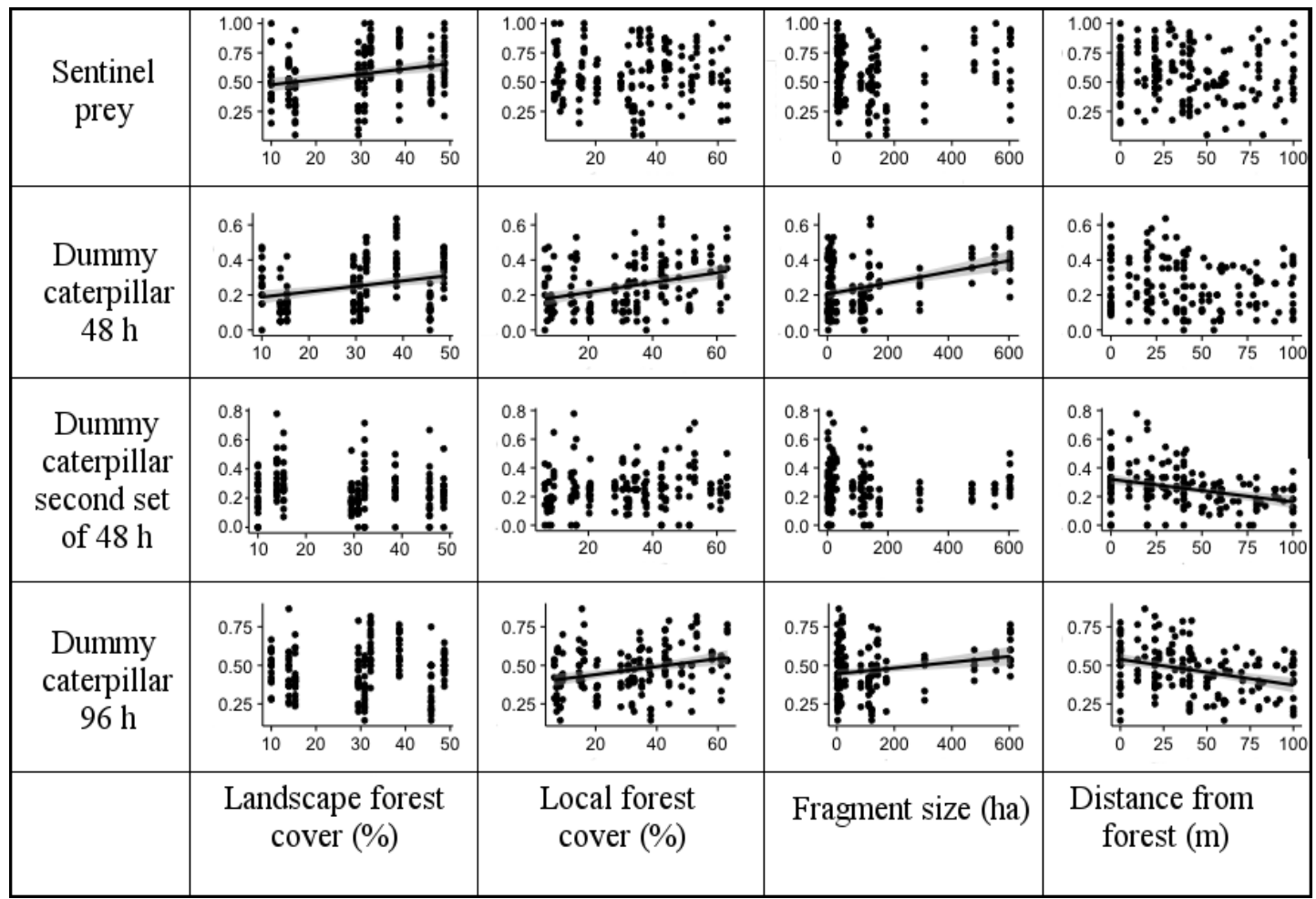

Figure 4: Simple relationships between predation rates (Y axes) and landscape metrics ( $\mathrm{X}$ axes) considering different methodological procedures. Graphs with trendlines represent significant relations $(\mathrm{p}<0.05)$. 


\section{Discussion}

Predation rates in pastures were affected by the surrounding landscape structure. However, the pattern of relationship changes according the type of method used to access the predation process. According to the sentinel prey experiment, predation rate in the matrix was weakly affected by landscape forest cover, while the positive effect of fragment size is more evident within the first 48 hours of exposure of the dummy caterpillars' experiment, and the negative effect of distance from forest is clearer in the second set of 48 hours as well within 96 hours of dummy caterpillars exposure.

\section{Landscape structural effects}

Predation rates in pastures were affected by the amount of forest cover, the fragment size and the distance (isolation) to those fragments.

The positive effect of landscape forest cover on predation rate can be explained by the importance of the amount of forest cover in agricultural areas to the provision of predatory species (Bianchi et al., 2006). Forest cover at the landscape level is positively related with the diversity of insectivorous bird species and invertebrate predators (Tscharntke et al. 2005, 2008), which may enhance invertebrate predation process (Jones et al., 2005; Philpott et al., 2009; Boesing et al., in press). Since low quality matrices as pastures have a less diversified community of insectivorous birds and invertebrate predators (Tscharntke et al. 2008), and it is known that the increase in species richness is positively related to the amount of removed preys (De la Mora et al., 2015), the amount of forest areas in the landscape play an important role 
in maintaining a more diversified community of potential natural enemies, favoring the service of pests control in low quality matrices.

The effect of fragment size can be explained by the fact that the size of the fragment is positively related to species diversity (Bruhl et al. 2003). The increase in species diversity may result in an increase in the number of species with similar functions, as insectivory, making the process derived from this attribute more resistant to disturbance (Hooper et al., 2005; Leal et al, 2012). Furthermore, increase in fragment size can also be related to an increase in the richness (Bruhl et al., 2003) and abundance of very effective predators (Huston, 1997; Tscharntke et al 2005), thus favoring ecological processes such as predation (De la Mora et al, 2015; Jordani et al, 2015). Smaller fragments have higher homogenization in their community composition and support smaller populations due to greater vulnerability to stochastic events (Connor et al., 2000; Bruhl et al. 2003; Leal et al, 2012.). Top-down regulation processes such as predation may be negatively affected by the loss of predator species due to reduced functional diversity of predators (Philpott and Armbrecht, 2006), and by the reduction in the abundance of potential predatory species (Bianchi and Wackers, 2008; Jordani et al, 2015).

The negative effect of isolation may be due to a more intense functional spillover of species towards the matrix near the edges. Matrices vastly dissimilar from the natural habitat, such as pasture matrix, can offer much resistance to the movement of these potential predators (Ricketts, 2001; Jules and Shahani, 2003). The reduction in species richness of some arthropods with the distance to forest fragment edge (Perfecto and Vandermeer, 2002; Armbrecht and Perfecto, 2003; Hendrickx et al, 2007; De la Mora et al, 2013), can make predation more intense next to natural areas (Trembley et al., 2001). Although our results 
show a clearly reducing predation pattern with increasing distance from forest fragment edge, the absence of this effect in shorter exposure times (48 hours) do not allow us to state that the mechanism by which the negative distance effect emerges is due solely to the functional spillover process.

Our results showed that in pasture matrix, which could be considered a low quality matrix, the surrounding landscape structure, particularly the amount of forest cover, the fragment size and the distance to those fragments, are related to the increase in predation rates. Since those low quality matrix are known for being hostile for most invertebrate predators (Tscharntke et al 2008), our results highlights the importance of maintaining native forest areas next to low quality matrix to allow the provision of natural pest control services, such as pasture sharpshooters' control.

Because pasture matrices are at an extreme in terms of low quality matrix (Guevara et al., 1992; Gascon et al., 1999), it is expected that matrices more similar to native habitat will favor even more movement over the matrix, and enhance functional spillover (Jules and Shahani, 2003; Jordani et al., 2015), extending thus pest control services inside matrix areas. However, this general pattern relating matrix quality to the extension of pest control should be the focus of further researches.

\section{Predation procedures affect pattern-process relationships}

In the sentinel prey experiment, the available prey is a real organism, that may be alive or dead (O'neal et al., 2005; Howe et al, 2009; De la Mora et al, 2015), and therefore sending chemical and visual real signals (Molleman et al., 2015). Since many predators use chemical and visual cues to prey recognition (Vet and Dicke, 1992; Molleman et al., 2015), it 
is expected that this type of experiment attract many chemically-oriented predators (e.g. most arthropods), and visually oriented predators (e.g. birds). On the other side, dummy caterpillars models are supposed to be more efficient in attracting visually oriented predators, since these models only look like real caterpillars, but do not have chemical signs of real caterpillars (Molleman et al., 2015). However, in the literature arthropods are the main documented predators in this type of experiment (eg Loiselle et al., 2002; Richard and Coley, 2007; Howe et al, 2009; Molleman et al, 2015), and this pattern was confirmed in our experiments, once 94 to $96 \%$ of the predations were related to arthropods. The higher predation rate of sentinel prey's experiment compared to dummy caterpillars' experiment may be thus a result of the attraction of both type of oriented predators by the real prey, while caterpillars are attracting almost exclusively arthropods.

The type of prey may affect the "scale of effect" (sensu Jackson and Fahrig 2012) of the observed predation process. Chemically-oriented predators, such as some arthropods, often respond to ecological factors at smaller spatial scales (Dauber et al. 2003; Ribeiro et al, 2012; De la Mora et al., 2013), while visually oriented predators such birds and mammals usually respond at larger scales. This is in accordance with the lack of effect of landscape forest cover and clear effects of local spatial parameters (fragment size, isolation, local forest cover) in the dummy caterpillars experiments. Although sentinel preys must have attracted both visual and chemically-oriented predators, since the landscape forest cover was the main predictor variable to explain the predation rate in this experiment, we can suppose that most predators for sentinel preys are birds that respond to the landscape structure at larger scales (Smith et al, 2011). 
Besides the type of prey, different exposure times of prey in dummy caterpillars experiments may also affect the perceived ecological patterns. In shorter exposure times (48 hours) predation proportion was influenced by local parameters, such as local forest cover and mainly by the size of the nearest forest fragment. At longer exposure times (96 hours) and at the second set of 48 hours, the influence of isolation (distance to the closest fragment) became clearer.

There were no initial expectations that isolation pattern would be accentuated with exposure time of prey. This pattern appears, after the first 48 hours, because predation rates were reduced far from forest edge, and increased near to forest, indicating a preference from predators to attack models near the forest edge. Since model disposal in the experiment was fixed, it is possible that predators got used to prey disposal and began to prey more intensely near to forest. Once most of dummy caterpillars' experiment predators were arthropods that can be predated (by birds) in the matrix, it should be less costly to forage near the forest edges. Predation preference near to forest may be thus due to the hostility of pasture matrix (Gascon et al., 1999), leading to a less diversified community of potential arthropods predators as we moved away from the forest fragments (Tscharntke et al 2008).

\section{Methodological implications}

This study provides the first empirical evidence that the type of experiment used to access the predation process influences the type of spatial pattern that emerges. In this context, we recommend to use more than one sampling method to access the predation process, particularly considering more than one type of prey and different exposure times of preys. 
The use of different sampling methods to access the predation process can increase the amount and the diversity of information that is obtained (Howe et al, 2009; Molleman et al, 2015), which can help to understand the mechanisms involved in the process (Howe et al., 2009). Particularly, the use of different types of prey can ensure that a greater diversity of predators to be attracted (Howe et al, 2009; Molleman et al, 2015). Because different predators can respond to different aspects of landscape structure and at different spatial levels (Jackson and Fahrig, 2015), attracting greater diversity of predators allows predation process to be more completely assessed. Also, as important as attracting different predators, is the ability to identify those predators and the ecological factors that are affecting them. The combination of effects from predators that act at different spatial scales may result in confused or unclear patterns. Thus, to ensure the understanding of the processes related to each group of predators, it is important that researchers be able to identify the predators, or at least to the main scale at which those predators are acting.

This study shows also that different times of prey exposure may result in revealing distinct ecological patterns. Because species responses to changes in landscape structure and resource availability may be temporally delayed (Metzger et al., 2009; Rybicki and Hanski, 2013), it is important to consider not only short exposure time, but also longer exposure times. Evaluate the predation process in multiple exposure times may facilitate the understanding of different ecological mechanisms that operate at different temporal scales (Lira et al., 2012).

Finally, it is important to note that standardized protocols are important to allow comparisons. When doing meta-analysis or using data from the literature, collected with different methods, one should be aware about the effects of the different methods on the observed pattern. 


\section{Final remarks}

This study highlights that natural forest cover and its spatial arrangement in agricultural landscapes can modulate predation process occurring in an agricultural matrix. Since the ecosystem service of pest control depends on the predation process (Wilby and Thomas, 2002; Howe et al, 2009), this study show that the provision of this service can be regulated by the landscape structure. Knowing that agricultural and livestock expansions tends to replace forests by cultivated or pasture areas (Tscharntke et al 2005; Rusch et al, 2016), agricultural landscape planning and management should be made in order to maximize the positive effects of forest cover in the provision of pest control and other ecosystem services (Tscharntke et al 2005; Howe et al., 2009). Also, our data is the first to suggest that the type of prey and the exposure time used to measure predation influence the observed ecological patterns, drawing then attention to the need to consider the method in the survey of new data and in the comparison of data already published.

\section{Acknowledgement}

We thank all the farmers and employees for the support and for giving us permission to conduct the fieldwork in their lands. To all volunteers and all the members of Interface Project that helped on the fieldwork, we would like to give our gratitude. Also we would like to specially thank all the staff in Lepac (Laboratory of Landscape Ecology and Conservation) for the great support and help. This study was founded by the São Paulo Research Foundation (FAPESP - 2013/23457-6), and by the Coordination for the Improvement of Higher Education Personnel (CAPES). 


\section{References}

Armbrecht, I. and Perfecto, I. 2003. Litter-twig dwelling ant species richness and predation potential within a forest fragment and neighboring coffee plantations of contrasting habitat quality in Mexico. Agriculture, Ecosystem and Environment 97, 107-115.

Andersen, A., Eltun, R. 2000. Long-term developments in the carabid and staphylinid (Col.,Carabidae and Staphylinidae) fauna during conversion from conventional to biological farming. Journal of Applied Entomology 124, 51-56.

Arzolla, F.A.R., vilela, F.E.S.P., Paula, G.C., Shepherd, G., Descio, F., Moura, C. 2011. Floristic composition and conservation of old secondary Forest in the serra Cantareira in São Paulo, South-Eastern Brazil. Revista do Instituto Florestal 23, 149-171.

Benton, T.G., Bryant, D.M., Cole, L., Crick, H.Q.P., 2002. Linking agricultural practice to insect and bird populations: a historical study over three decades. Journal of Applied Ecology 39, 673-687.

Bianchi, F.J.J.A., Booij, C.J.H., Tscharntke, T. 2006. Sustainable pest regulation in agricultural landscapes: a review on landscape composition, biodiversity and natural pest control. Proceedings of the Royals Society 273, 1715-1727.

Bianchi, F.J.J.A., and Wackers, F.L. 2008. Effects of flower attractiveness and nectar availability in field margins on biological control by parasitoids. Biological Control 46, 400-408.

Blitzer, E.J., Dormann, C.F., Holzschuh, A., Klein, A., Rand, T.A., Tscharntke, T. 2012. Spillover of functionally important organisms between managed and natural habitats. Agriculture, Ecosystems and Environment 146, 34- 43.

Boesing, A.L., Nichols, E., Metzger, J.P. Effects of landscape structure on avian-mediated pest control services. Submitted

Bruhl, C.A., Eltz, T., Linsenmair, K.E. 2003. Size does matter - effects of tropical rainforest fragmentation on the leaf litter ant community in Sabah, Malaysia. Biodiversity and Conservation 12, 1371-1389.

Cardinale, B.J., Duffy J.E., Gonzalez A., Hooper D.U., Perrings C., Venail P., Narwani A., Mace G.M., Tilman D., Wardle D.A., Kinzig A.P., Daily G.C., Loreau M., Grace J.B., Larigauderie A., Srivastava S.D., Naeem S. 2012. Biodiversity loss and its impact on humanity. Nature 486, 59-67.

Connor ,E.F., Courtney, A.C., Yoder, J.M. 2000. Individuals-area relationships: the relationship between animal population density and area. Ecology 81, 734-748. 
Costanza R. 2008. Ecosystem services: Multiple classification systems are needed. Biological conservation 141: 350 - 352.

Crawley MJ (ed.) (1992) Natural Enemies. Blackwell, Oxford,UK.

Dauber, J., Hirsch, M., Simmering, D., Waldhardt, R., Otte, A., Wolters, V. 2003. Landscape structure as an indicator of biodiversity: matrix effects on species richness. Agriculture, Ecosystems and Environment 98, 321-329.

De la Mora, A.A., García-Ballinas, J.A., Philpott, S.M. 2015. Local, landscape, and diversity drivers of predation services provided by ants in a coffee landscape in Chiapas, Mexico. Agriculture, Ecosystems and Environment 201, 83-91.

De la Mora, A.A., Murnen, C.J., Philpott, S.M. 2013. Local and landscape drivers of biodiversity of four groups of ants in coffee landscapes. Biodiversity Conservation 22, 871-888.

Foley J.A., DeFries R., Asner G.P., Barford C., Bonan G., Carpenter S.R., Chapin F.S., Coe M.T., Daily G.C., Gibbs H.K., Helkowski J.H., Holloway T., Howard E.A., Kucharik C.J., Monfreda C., Patz J.A., Prentice C., Ramankutty N., Snyder P.K., 2005. Global Consequences of Land Use. Science 309, 570-574.

Gallo, D., Nakano, O., Silveira Neto, S., Carvalho, R. P. L., Baptista, G. C., Berti Filho, E., Parra, J. R. P., Zucchi, R. A., Alves, S. B., Vendramim, J. D., Marchini, L.C., Lopes, J. R. S., Omoto, C. 2002. Entomologia Agrícola. Piracicaba, FEALQ. 920p.

Gascon, C., Lovejoy, T.E., Bierregaard Jr., R.O., Malcolm, J.R., Stouer, P.C., Vasconcelos, H.L., Laurance, W.F., Zimmerman, B., Tocher,M., Borges, S. 1999. Matrix habitat and species richness in tropical forest remnants. Biological Conservation 91, 223-229.

Guevara, S., Meave, J., Moreno-Casasola, P., Laborde, J. 1992. Floristic composition and structure of vegetation under isolated trees in neotropical pastures. Journal of Vegetation Science 3, 655-664.

Hendrickx, F, Maelfait, J., Van Wingerden, W., Schweiger, O., Speelmans, M., Aviron, S., Augentein, S., Billeter, L., Bailey, D., Bukacek, R., Burel, R., Dienkotter, T., Dirksen, J., Herzog, F., Liira, J., Roubalova, M., Vandomme, V., Bugter, R. 2007. How landscape structure, land-use intensity and habitat diversity affect components of total arthropod diversity in agricultural landscapes. Journal of Applied Ecology 44, 340-351.

Holland, J. and Fahrig, L. 2000. Effect of woody borders on insect density and diversity in crop fields: a landscape-scale analysis. Agric. Ecosyst. Environ. 78, 115-122.

Hooper, D. , Chapin , F. , III , Ewel , J. , Hector , A. , Inchausti , P. , Lavorel , S ., Lawton , J ., Lodge , D. , Loreau , M. , Naeem , S. , Schmid, B. , Setälä , H. , Symstad, A ., Vandermeer , J .,Wardle , 
D. 2005. Effects of biodiversity on ecosystem functioning: a consensus of current knowledge. Ecological Monographs 75, 3-35.

Howe, A., Lövei, G.L., Nachman, G. 2009. Dummy caterpillars as a simple method to assess predation rates on invertebrates in a tropical agroecosystem. Entomologia Experimentalis et Applicata 131, 325-329.

Huston, M.A. 1997. Hidden treatments in ecological experiments: reevaluating the ecosystem function of biodiversity. Oecologia 110, 449-460.

Informe Itambé. 2013. Cigarrinhas-das-pastagens geram prejuizos em torno de U\$800 milhões por ano no Brasil. Disponível em: http://www.itambe.com.br/download/2828/cadernoAgropecuario.as px.

Isaacs, R., Tuell, J., Fiedler, A., Gardiner, M., Landis, D. 2009. Maximizing arthropod-mediated ecosystem services in agricultural landscapes: the role of native plants. Front Ecol Environ 7(4): 196203.

Jackson, H.B. and Fahrig, L. 2012.What size is a biologically relevant landscape? Landscape Ecology 27, 929-941.

Jackson, H.B. and Fahrig, L. 2015. Are ecologists conduction research at optimal scales? Global Ecology and Biogeography 24, 52-63.

Jules, E.S., Shahani, P. 2003. A broader ecological context to habitat fragmentation: why matrix habitat is more important than we thought. Journal of Vegetation Science 14, 459-464.

Jones, G.A., Sieving, K.E., Jacobson, S. K. 2005. Avian diversity and functional insectivory on north-central Florida farmlands. Conservation Biology 19, 1234-1245.

Koller, W.W., 1988. Ocorrência de cigarrinhas-das-pastagens e de seu predador natural sob o efeito de sombreamento Salpingogaster nigra Schiner. Documentos 37, Campo Grande MS, EMBRAPA Gado de corte.

Landis, D.A., Wratten, S.D., Gurr, G.M., 2000. Habitat management to conserve natural enemies of arthropod pests in agriculture. Annual Review of Entomology 45, 175-201.

Langellotto, G.A. Denno, R.F. 2003. Responses of invertebrate natural enemies to complex-structured habitats: a meta-analytical synthesis. Oecologia 139, 1-10.

Leal, I.R., Filgueiras, B.K.C., Gomes, J.P., Iannuzzi, L., Andersen, A.N. 2012. Effects of habitat fragmentation on ant richness and functional composition in Brazilian Atlantic forest. Biodiversity and Conservation 21, 1687-1701.

Lira, P.K., Ewers, R.M., Banks-Leite, C., Pardini, R., Metzger, J.P. 2012. Evaluating the legacy of landscape history: extinction debt and 
species credit in bird and small mammal assemblages in the Brazilian Atlantic Forest. Journal of Applied Ecology, 1325-1333.

Loiselle, B.A. and Farji-Brener, A.G. 2002. What's Up? An experimental comparison of predation levels between canopy and understory in a tropical wet forest. Biotropica 34, 327-330.

McGarigal, K., S. A. Cushman, M. C. Neel, and E. Ene. 2002. FRAGSTATS: Spatial Pattern Analysis Program for Categorical Maps. Computer software program produced by the authors at the University of Massachusetts, Amherst. Available at the following web site: http://www.umass.edu/landeco/research/fragstats/fragstats.html

Meyer, S.T., Koch, C., Wolfgang W.W. 2015. Towards a standardized Rapid Ecosystem Function Assessment (REFA). Trends in Ecology \& Evolution 30, 390-397.

Metzger, J.P., Martensen, A.C., Dixo, M., Bernacci, L.C., Ribeiro, M.C., Teixeira, A.M.G., Pardini, R. 2009. Time-lag in biological responses to landscape changes in a highly dynamic Atlantic forest region. Biological Conservation 142, 1166-1177.

Millennium Ecosystem Assessment. 2005. Ecosystems and Human Wellbeing: Biodiversity Synthesis (World Resources Institute, 2005).

Mittermeier, R.A., Fonseca, G.A.B., Rylands, A.B., Brandon, K. 2005. A Brief History of Biodiversity Conservation in Brazil. Conservation Biology 19, 601-607.

MMA, 2007.Áreas prioritárias para conservação, uso sustentável e repartição de benefícios da biodiversidade Brasileira: Atualização Portaria MMA de 23 de janeiro de 2007. In: MMA/SBF 9, 300.

Molleman, F., Remmel, T., Sam, K. 2015. Phenology of predation on insects in a tropical forest: temporal variation in attack rate on dummy caterpillars. Biotropica, 1-8.

Myers, N., Mittermeier, R.A., Mittermeier, G.G., Fonseca, G.A.B., Kent, J. 2000. Biodiversity hotspots for conservation priorities. Nature 403, 853-858.

Nogueira da Costa, F. 2011. Crescimento da Fronteira Agrícola no Estado de São Paulo. Disponível em: http://fernandonogueiracosta.wordpress.com/2011/05/05/cresciment o-da-fronteira-agricola-no-estado-de-sao-paulo/.

Oliveira, M. C. 1997. Pragas das pastagens: uma análise crítica. Disponível em: http://www.forragicultura.com.br/arquivos/Pragas_de_pastagens.PD F.

O'neal, M.E., Zontek, E.L., Landis, D.A., Isaacs, R. 2005. Ground predator abundance affects prey removal in highbush blueberry 
(Vaccinium corymbosum) fields and can be altered by aisle ground covers. BioControl 50, 205-222.

Ostman, O., Ekbom, B., Bengtsson, J. 2003 Yield increase attributable to aphid predation by ground-living polyphagous natural enemies in spring barley in Sweden. Ecol. Econ. 45, 149-158.

Perfecto, I. and Vandermeer, J. 2002. Quality of agroecological matrix in a tropical montane landscape: ants in coffee plantations in Southern Mexico. Conservation Biology 16, 174-182.

Perfecto, I., Vandermeer, J.H., Bautista, G.L., Nunez, G.I., Greenberg, R., Bichier, P., Langridge, S. 2004. Greater predation in shaded coffee farms: the role of resident Neotropical birds. Ecology 85, 2677-2681.

Philpott, S.M ., Armbrecht, I. 2006. Biodiversity in tropical agroforests and the ecological role of ants and ant diversity in predatory function. Ecological Entomology 31, 369-377.

Philpott, S.M., Soong,O., Lowenstein, J.H., Pulido, A.L., Lopez, D.T., Flynn, D.F.B., DeClerck, F. 2009. Functional richness and ecosystem services: bird predation on arthropods in tropical agroecosystems. Ecol Appl 19,1858-1867.

Prasifka, J.R., Heinz, K.M. 2004. The use of C3 and C4 plants to study natural enemy movements and ecology, and its application to pest management. International Journal of Pest Management 50: 177181.

Puckett, H. L., Brandle J.R., Johnson R.J., Blankenship E.E., 2009. Avian foraging patterns in crop field edges adjacent to woody habitat. Agriculture, Ecosystems and Environment 131 9-15.

R Development Core Team, 2004. R: a language and environment for statistical computing. R Foundation for Statistical Computing, Vienna. URL http://www.R-project.org.

Ribeiro, D.B., Batista, R., Prado, P.I., Brown Jr, K.S., Freitas, A.V.L. 2012. The importance of small scales to the fruit-feeding butterfly assemblages in a fragmented landscape. Biodiversity Conservation $21,811-827$.

Richards, L.A. and Coley, P.D. 2007. Seasonal and habitat differences affect the impact of food and predation on herbivores: a comparison between gaps and understory of a tropical forest. Oikos 116, 31-40.

Ricketts, T.H. 2001.The Matrix Matters: Effective Isolation in Fragmented Landscapes. The American Naturalist 158, 87-99.

Rodrigues, R.R., Bononi, V.L.R. 2008 Diretrizes para conservação e restauração da biodiversidade no Estado de São Paulo. Instituto de Botânica. Programa Biota/FAPESP.

Roger, C., Coderre, D. and Boivin, G. 2000. Differential prey utilization by the generalist predator Coleomegilla maculata lengi according to 
prey size and species. Entomologia Experimentalis et Applicata 94, $3-13$.

Romitelli, I. 2015. Variabilidade espacial nos estoques de carbono em paisagens fragmentadas de Mata Atlântica. Dissertação de mestrado, Universidade de São Paulo, Brasil.

Rosenheim, J.A., Wilhoit, L.R., Armer, C.A. 1996. Influence of intraguild predation among generalist insect predators on the suppression of an herbivore population. Oecologica 96, 439-449.

Rybicki, J., Hanski, I. 2013. Species-area relationships and extinctions caused by habitat loss and fragmentation. Ecology Letters 16, 2738.

Rusch, A., Valantin-Morison, M., Sarthou, J.P., Roger-Estrade, J. 2010. Biological control of insect pests in agroecosystems: effects of crop management, farming systems, and seminatural habitats at the landscape scale: a review. Advances in Agronomy 109, 219-259.

Rusch, A., Chaplin-Kramer, R., Gardiner, M.M., Hawro, V., Holland, J., Landis, D., Thies, C., Tscharntke, T., Weisser, W.W., Winqvist, C., Woltz, M., Bommarco, R. 2016. Agricultural landscape simplification reduces natural pest control: A quantitative synthesis. Agriculture, Ecosystems and Environment 221, 198-204.

Sam, K., Remmel, T. and Molleman, F. 2015. Material affects attack rates on dummy caterpillars in tropical forest where arthropod predators dominate: an experiment using clay and dough dummies with green colourants on various plant species. Entomologia Experimentalis et Applicata 157, 317-324.

Smith, A.C., Fahrig, F., Francis, C.M. 2011. Landscape size affects the relative importance of habitat amount, habitat fragmentation, and matrix quality on forest birds. Ecography 34,103-113.

Sodhi N.S., Brook B.W. Bradshaw C.J.A., 2009. Causes and consequences of Species Extinctions. Pp. 514-520 in Levin, S. A. (eds). The Princeton Guide to Ecology. Princeton University Press, Princeton, USA.

Storch I., Woitke, E. e Krieger, S., 2005. Landscape-scale edge effect in predation risk in forest-farmland mosaics of central Europe. Landscape Ecology 20, 927-940.

Tilman, D., Cassman, K.G., Matson, P.A., Naylor, R., Polansky, S. 2002. Agricultural sustainability and intensive production practices. Nature 418, 671-677.

Tremblay, A., Mineau, P. Stewart, R.K. 2001. Effects of bird predation on some pest insect populations in corn. Agriculture, Ecosystems and Environment 83, 143-152.

Tscharntke, T., Klein, A.M., Kruess, A., Steffan-Dewenter, I., Thies, C. 2005. Landscape perspectives on agricultural intensification and 
biodiversity - ecosystem service management. Ecology Letters 8, 857-874.

Tscharntke, T., Sekercioglu, C.H., Dietsch, T.V., Sodhi, N.S., Hoehn, P. and Tylianakis, J.M. 2008. Landscape constraints on functional diversity of birds and insects in tropical agroecosystems. Ecology 89, 944-951.

Valério, J.R., Nakano, O. 1988. Danos causados pelo adulto da cigarrinha Zulia entreriana na produção e qualidade de Brachiaria decumbens. Pesquisa Agropecuária Brasileira 23, 447-453.

Valério, J. R., Oliveira, C.M. 2005. Parasitismo de ovos de cigarrinhasdas-pastagens (Homoptera: Cercopidae) pelo microhimenóptero Anagrus urichi Pickles (Hymenoptera: Mymaridae) na região de Campo Grande, MS. Neotropical Entomology, 34, 137-138.

Ventura, A. Problemas Técnicos da Silvicultura Paulista. 1964. Revista Técnica do Serviço Florestal do Estado de São Paulo, São Paulo 3, 61-80.

Vet, L.E.M and Dicke, M. 1992. Ecology of infochemical use by natural enemies in a tritrophic context. Annual Review of Entomology 37, $141-172$.

Wilby, A. Thomas, M.B., 2002. Natural enemy diversity and pest control: patterns of pest emergence with agricultural intensification. Ecology Letters 5, 353-360.

With, K.A., Pavuk, D.M., Worchuck, J.L., Oates, R.K., Fisher, J.L. 2002. Threshold effects of landscape structure on biological control in agroecosystems. Ecological Applications 12, 52-65.

Whatley, N., Cunha, P. 2007. Um olhar sobre o maior manancial de água da Região Metropolitana de São Paulo. In, Resultados do diagnóstico participativo do Sistema Cantareira. Instituto Socioambiental, São Paulo, SP.

Zuur, A.F. 2009 Mixed effects models and extensions in ecology with R. Springer, New York ; London, pp. 574. 


\section{Supplementary material}
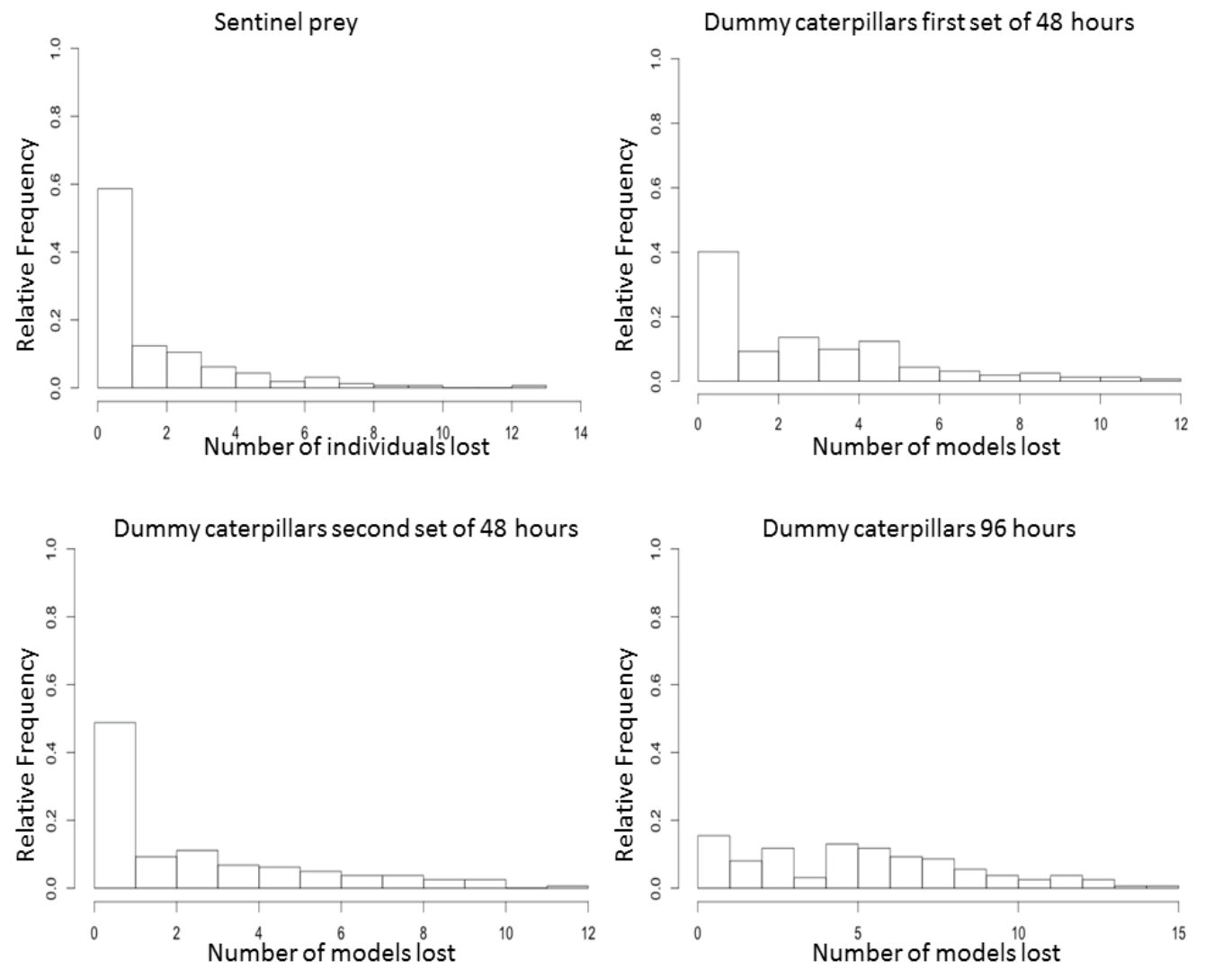

Figure S1: Histogram with the number of individuals/models lost by experiment: sentinel prey $($ mean $=9 \%)$; dummy caterpillars first 48 hours $($ mean $=14 \%)$; dummy caterpillars second set of 48 hours (mean $=18 \%$ ); and dummy caterpillars 96 hours $($ mean $=27 \%)$. 


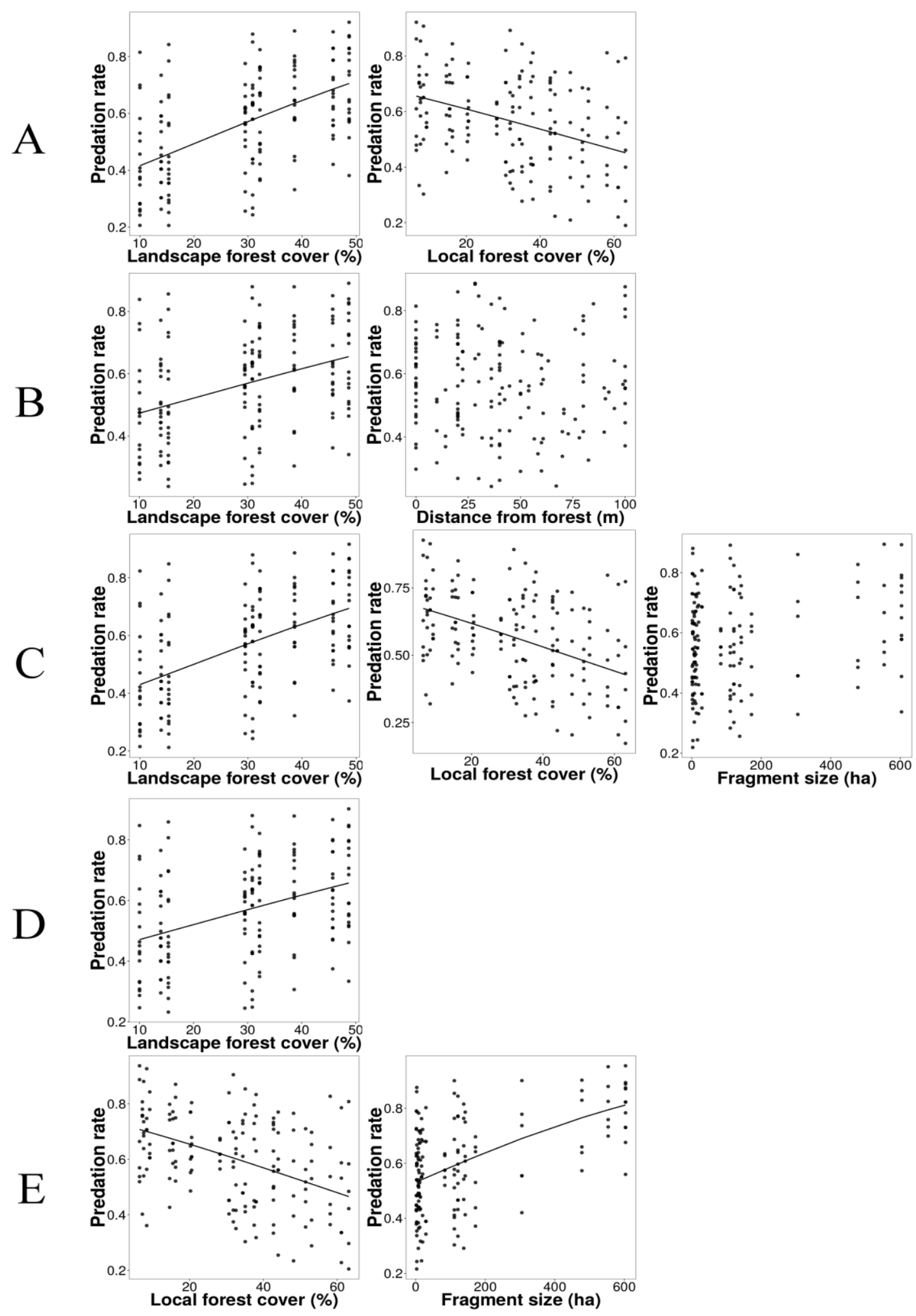

Figure S2: Models obtained with the sentinel prey experiment relating predation rate with landscape structural metrics (see Table 1). Graphs with lines have significant relationships. A. Landscape forest cover + Local forest cover; B. Landscape forest cover * Distance from forest; C. Landscape forest cover; D. Landscape forest cover + Local forest cover + Fragment size; E. Landscape forest cover + Local forest cover + Fragment size. 


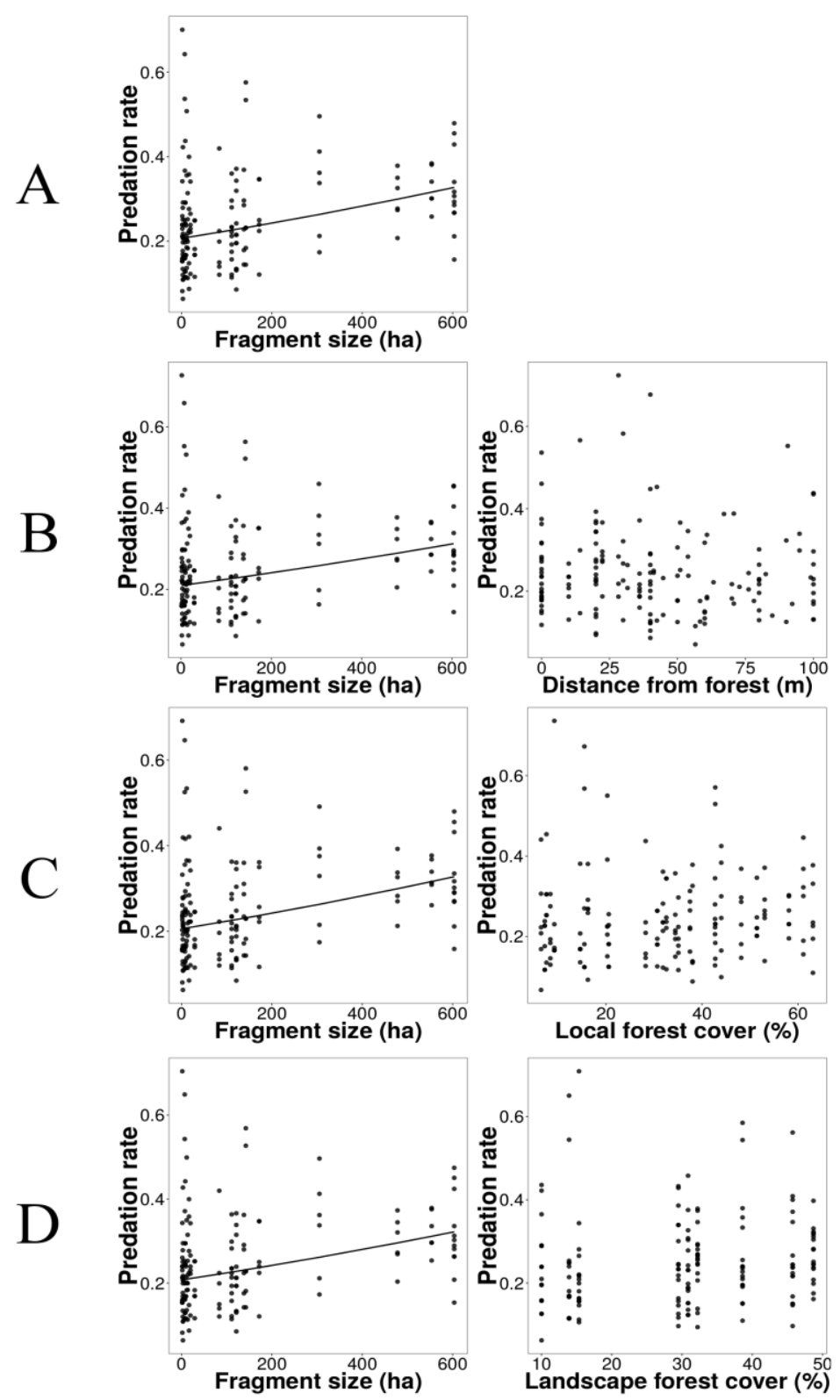

Figure S3: Models obtained with the dummy caterpillars'48 hours experiment relating predation rate with landscape structural metrics (see Table 1). Graphs with lines have significant relationships. A. Fragment size; B. Fragment size + Local forest cover; C. Fragment size + Distance from forest; D. Fragment size + Landscape forest cover. 


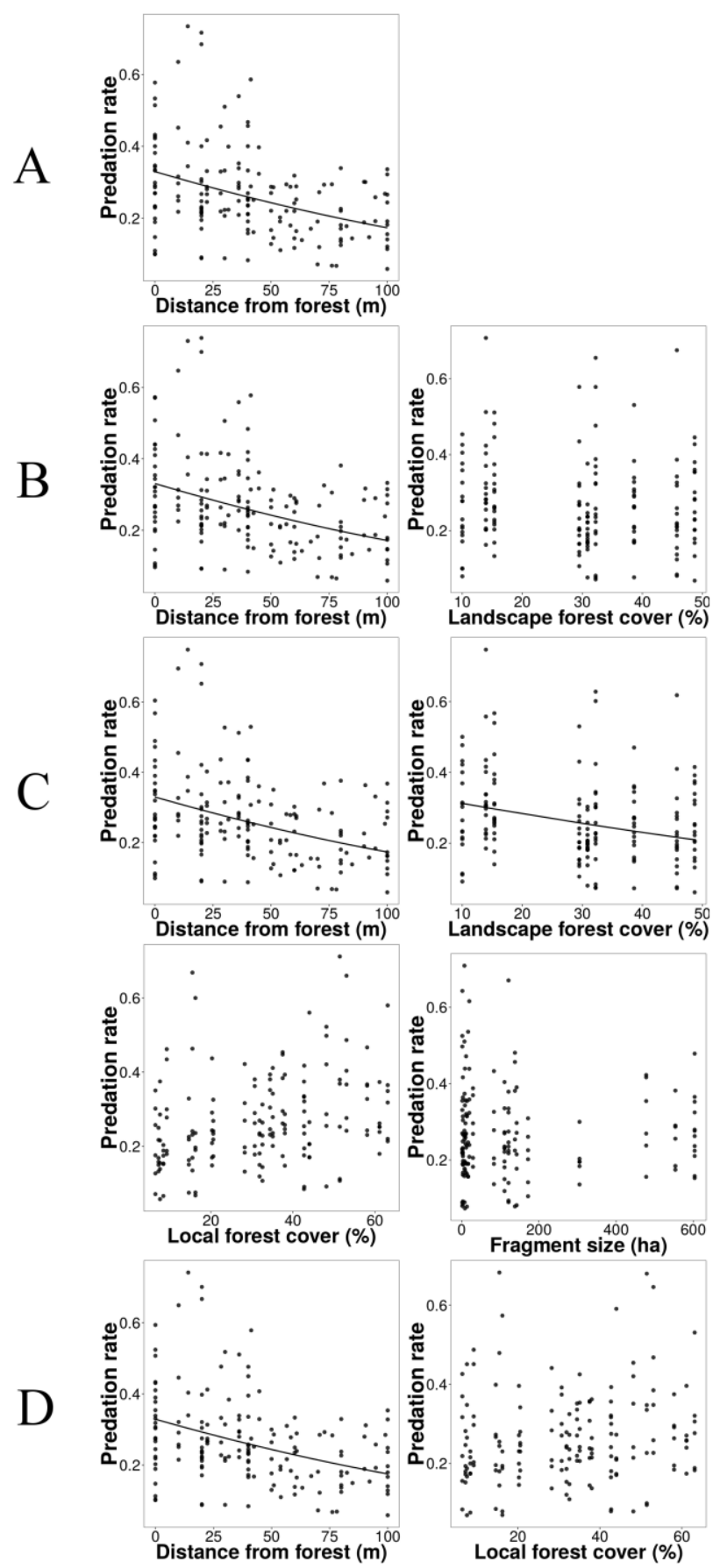

Figure S4: Models obtained with the dummy caterpillars' second set of 48 hours experiment relating predation rate with landscape structural metrics (see Table 1). Graphs with lines have significant relationships. A. Distance from forest; B. Distance from forest + Landscape forest cover; C. Distance from forest + Landscape forest cover + Local forest cover + Fragment size; D. Distance from forest + Local forest cover. 


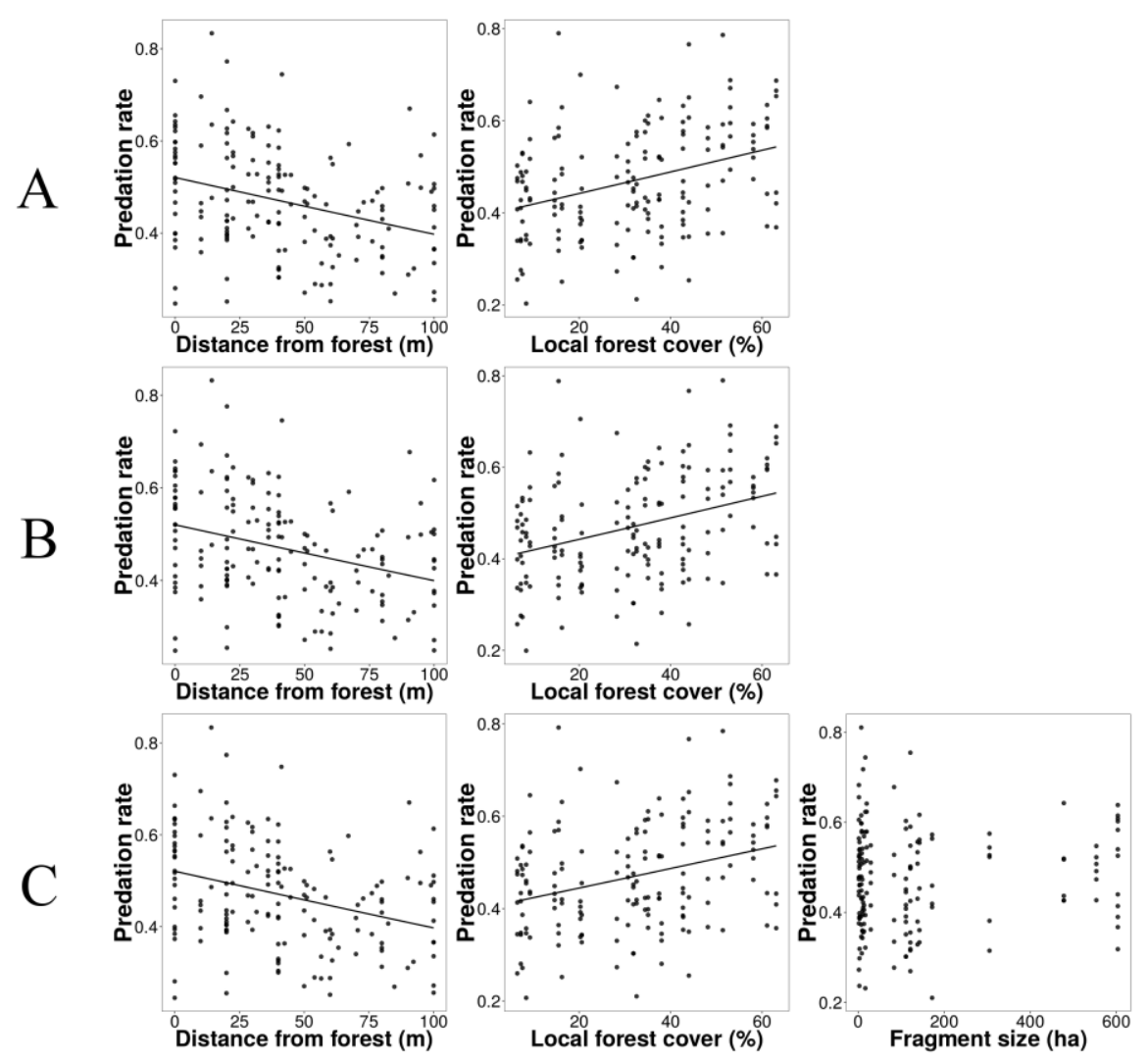

Figure S5: Models obtained with the dummy caterpillars' 96 hours experiment relating predation rate with landscape structural metrics (see Table 1). Graphs with lines have significant relationships. A. Distance from forest+ Local forest cover; B. Distance from forest*Local forest cover; C. Distance from forest+ Local forest cover + Fragment size. 


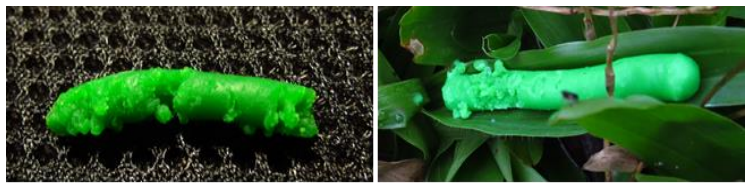

A
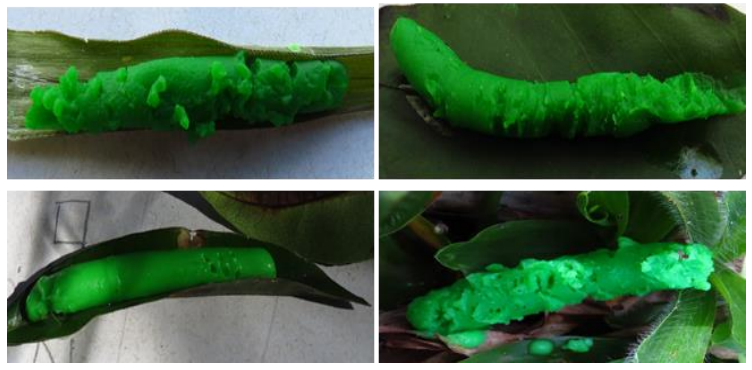

B
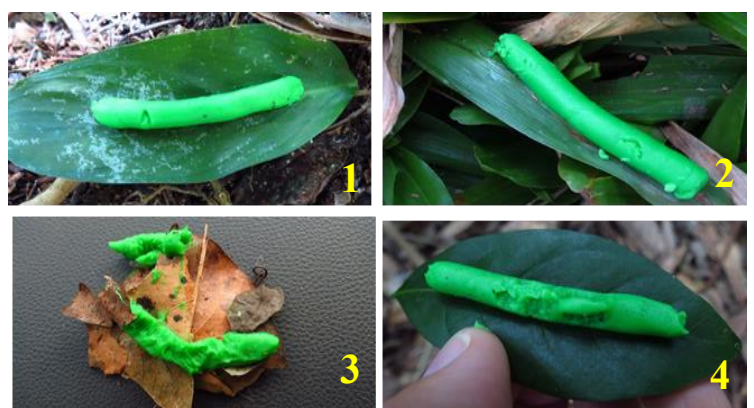

Figure S6: Examples of predators' marks of: A. Arthropods, B. Birds (1) and Mammals $(2,3,4)$.
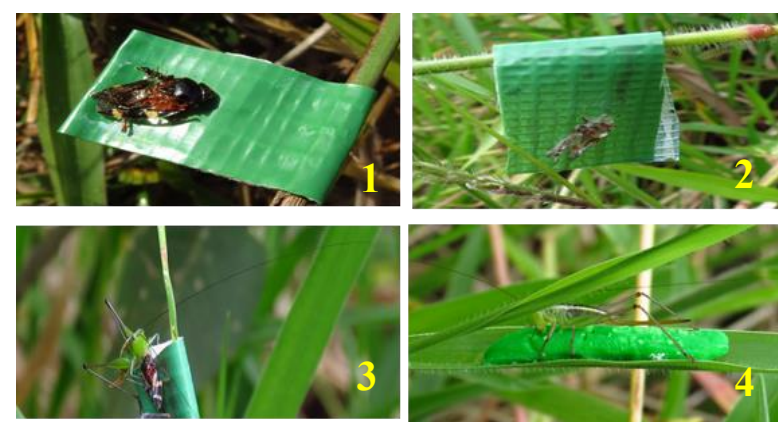

Figure S7: Example of individuals of Deos flavopica used in sentinel prey's experiments $(1,2)$; and individual and model being preyed by a grasshopper. 


\section{Conclusão final}

Nesse estudo nós mostramos que a estrutura da paisagem modula o processo de predação em matrizes de pastagem, mas a padrão encontrado depende do procedimento metodológico usado para acessar o processo. Em particular, o processo de predação na matriz está associado à cobertura florestal em níveis espaciais menores (raio de $400 \mathrm{~m}$ ), e é apenas fracamente afetado pela cobertura florestal no nível da paisagem. O tamanho do fragmento e a distância ao fragmento também são bons preditores do processo de predação em matrizes de pastagem.

Os padrões observados variam de acordo com o tipo de experimento e o tempo de exposição destes. Experimentos com presas reais (sentinel prey) parecem atrair em maior quantidade grupos taxonômicos que possuem escala de efeito mais ampla, no nível da paisagem. Por outro lado, experimentos com presas artificiais (dummy caterpillars) atraem principalmente grupos taxonômicos com escalas de efeito mais restritas, em níveis espaciais menores. Além disso, para o mesmo experimento (dummy caterpillars), o tempo de exposição das presas influencia o padrão observado, evidenciando padrões distintos em tempos distintos de exposição.

Dessa forma, esse estudo auxilia na compreensão das relações entre o processo de predação e a estrutura da paisagem. Particularmente, nós mostramos que as áreas florestais imersas em matrizes de pastagem possuem influencia positiva no processo de predação, sendo, portanto importantes na manutenção do serviço ecossistêmico de controle de pragas. Devido a isso, o manejo adequado das paisagens agropecuárias deve incluir a manutenção das áreas florestais imersas nessas matrizes, com especial atenção para a quantidade de áreas florestais superiores a 
$40 \%$, fragmentos maiores que 200 ha e o isolamento desses fragmentos, com o processo de predação mais intenso nos $50 \mathrm{~m}$ mais próximos a mata. Além disso, estudos que visam explorar o processo de predação devem considerar a influencia dos procedimentos metodológicos nos padrões ecológicos que podem emergir. Esses estudos devem prestar particular atenção ao tipo de presa que é disponibilizada nos experimentos e ao tempo de exposição dessas presas. 